\title{
Product complexity and operational performance: A systematic literature review
}

Trattner, Alexandria Lee; Hvam, Lars; Forza, Cipriano; Herbert-Hansen, Zaza Nadja Lee

\section{Published in:}

CIRP Journal of Manufacturing Science and Technology

Link to article, DOI:

10.1016/j.cirpj.2019.02.001

Publication date:

2019

Document Version

Peer reviewed version

Link back to DTU Orbit

Citation (APA):

Trattner, A. L., Hvam, L., Forza, C., \& Herbert-Hansen, Z. N. L. (2019). Product complexity and operational performance: A systematic literature review. CIRP Journal of Manufacturing Science and Technology, 25, 69-83. https://doi.org/10.1016/j.cirpj.2019.02.001

\section{General rights}

Copyright and moral rights for the publications made accessible in the public portal are retained by the authors and/or other copyright owners and it is a condition of accessing publications that users recognise and abide by the legal requirements associated with these rights.

- Users may download and print one copy of any publication from the public portal for the purpose of private study or research.

- You may not further distribute the material or use it for any profit-making activity or commercial gain

- You may freely distribute the URL identifying the publication in the public portal 


\section{Product complexity and operational performance: A systematic literature review}

Alexandria Trattner*, Lars Hvam, Cipriano Forza, and Zaza Nadja Lee Herbert-Hansen

*Alexandria Trattner, Industrial PhD candidate

Technical University of Denmark, DTU Management Engineering, Produktionstorvet, Building 424, 2800

Kongens Lyngby, Denmark

alemo@dtu.dk

ORCiD: 0000-0002-1115-4203

Lars Hvam, Professor

Technical University of Denmark, DTU Management Engineering, Produktionstorvet, Building 424, 2800

Kongens Lyngby, Denmark

lahv@dtu.dk

ORCiD: 0000-0002-7617-2971

Cipriano Forza, Professor

Department of Management and Engineering, University of Padova, Stradella san Nicola

36100 Vicenza, Italy

cipriano.forza@unipd.it

Zaza Nadja Lee Herbert-Hansen, Assistant Professor

Technical University of Denmark, DTU Management Engineering, Produktionstorvet, Building 424, 2800

Kongens Lyngby, Denmark

ORCiD: 0000-0003-3722-7017

nadhan@fiskeristyrelsen.dk

\section{Abstract}

This study presents a systematic literature review of the recent scholarly literature on product complexity (number, diversity, and interrelatedness of product variants and components) and manufacturing operational performance (measured in cost, time quality, and delivery reliability), considering the manufacturing context as well as the mechanisms behind the relationships. The results show that product complexity has a consistently negative relationship with cost, time, quality, and delivery performance measures, though the relationships with quality and delivery performance are less clear.

Keywords: Product Variety, Product Complexity, Operational Performance, Manufacturing, Complexity Management

Acknowledgements: The researchers thank the Innovation Fund of Denmark for its sponsorship of this research. 


\section{Product complexity and operational performance: A systematic literature review}

\section{Introduction}

\subsection{Background}

Increased competition, globalization, and increasing customer demand for unique products have led to a drastic increase in the number of product offerings in manufacturing firms (Bayus and Putsis, 1999; Quelch and Kenny, 1995; Silveira, 1998; Stäblien et al., 2011). Consumer packaged goods firms growing their stock keeping units (Quelch and Kenny, 1995), Philips expanding into 60 product categories by 2011, and LEGO doubling the number of unique brick types from 1997 to 2004 (Mocker and Ross, 2017) are just a few manifestations of the effects of increased product complexity on modern industry. This increase in product offerings can cause complexity in organizations, damaging operational performance as measured in labor costs, factory overhead costs, and productivity (Fisher and Ittner, 1999; Ittner and MacDuffie, 1995; MacDuffie et al., 1996; Mocker and Ross, 2017; Wilson and Perumal, 2009). Since operational performance and manufacturing strategy are keys to competitiveness and overall business performance (Fine and Hax, 1985), it is critical that manufacturing firms understand the impacts of complex product offerings on operational performance, such as time, cost, quality, and delivery. Understanding the impacts on lead time and delivery reliability is even more imperative now in the era of competing supply chains, in which companies must increase their flexibility towards the customer in terms of logistics, lead time, reliability, and variety (Christopher, 2000).

Previous studies on the impact of product complexity on overall firm performance have not focused on the effects on operational performance in manufacturing systems (Brun and Pero, 2012; ElMaraghy et al., 2013; Ramdas, 2003). Silveira (1998) offered a short review of literature on the operational impacts of product complexity, but it is constrained to dated studies from the late 1980s to early 1990s. A more recent review on product variety management emerged in 2013 and discusses management interventions intended to cope with increased product variants, but the exact impact of product complexity in the absence of interventions is not explored (Reis et al., 2013).

As the literature on the product complexity-performance relationship has accumulated, researchers have identified a set of strong linkages within the manufacturing and supply chain contexts; however, there has been little effort to synthesize the overall trends in this literature using a structured approach. As two authors studying production costs state, "the nature of [the product complexity-cost relationship] is not clear, and empirical evidence about whether and how production cost increases with variety is inconclusive” (Xia and Rajagopalan, 2009, p. 890). It is not known which operational performance measures provide conclusive evidence of a trend and which require further investigation. Furthermore, there is little understanding of how product complexity impacts different production system designs. The need for more work in this area is echoed by Stäblien et al. (2011), who stated that "in many ways we still have only a limited understanding of how variety impacts on the manufacturing system, and how to counter this impact effectively and efficiently" (Stäblien et al., 2011, p. 351). To the best of our knowledge, there has been no comprehensive overview of the literature assessing the relationships between product complexity (PC) and measures of operational performance (OP).

\subsection{Research Questions and Contribution}

The objective of this research is to synthesize the relationships between PC and specific measures of OP in the recent scholarly literature and reveal directions for future research using a 
structured literature review. Systematized understanding of which product complexity-performance relationships have conclusive evidence of a positive or negative tendency will form a basis of what is known and what needs to be explored further. Additionally, practitioners will benefit from knowing and anticipating the effects of increasing PC within their industry-specific manufacturing systems so they can plan appropriate interventions. Such an overview would reveal where manufacturers can expect increased PC to impact both internal and external performance measures, allowing a tailored management approach based on competitive priorities.

This article builds on a previous work by Trattner et al. (2017) and advances the method in the following ways. First, the search string was made more comprehensive to cover missing operational performance measures. Second, the study was expanded from process manufacturing systems to all types of manufacturing systems to increase generalizability. Furthermore, the terminology was made more succinct by referring to all product variety- and product complexity-related terms as product complexity. The authors believe these changes increase the relevance and simplicity of this article for the academic community as well as for practitioners.

In this study, we seek to meet the research need using a systematic literature review. Exploration of the literature is guided by a set of three research questions developed by the authors:

\section{RQ1 Which $P C \rightarrow O P$ relationships are most supported by the literature? \\ RQ2 Which $P C \rightarrow O P$ relationships still need further investigation? \\ RQ3 What are the most explored/underexplored types of production in the literature discussing the $P C \rightarrow O P$ relationship?}

The first and second research questions seek to identify the consolidated and fragmented areas of research on the $\mathrm{PC} \rightarrow \mathrm{OP}$ relationship to inform managers and guide future research. The third research question will contribute to better understanding the PC $\rightarrow$ OP relationships, considering the industry context and respective production systems. This set of research questions responds to the calls of Stäblien et al. (2011) and Xia and Rajagopalan (2009) for a synthesis of empirical evidence supporting the $\mathrm{PC} \rightarrow \mathrm{OP}$ relationships in different manufacturing systems.

\subsection{Product Complexity}

Defining constructs clearly is a necessary precursor to a systematic literature review. The term product complexity has no consistent definition in the management and engineering literature, making the operationalization of the construct difficult (Lindemann et al., 2010). Despite this lack of clarity, PC has been described in the literature as having many dimensions, including the number of components, the number of modules, the number of finished good variants in a portfolio, the number of interrelations between components, the commonality of products in an assortment, and the diversity of relations between components (Jacobs, 2013; Jacobs and Swink, 2011; Lindemann et al., 2010). In this literature study, PC will be an umbrella term covering measures of the variety, diversity, and interrelatedness of a single product or range of products in a production system. PC will also encompass related terms, such as product customization, product diversification, and similar terms. Product variety was also considered as the primary construct to study, but it was found to be an element of PC. Thus, PC was chosen for analysis.

\subsection{Operational Performance}

OP has been defined in previous work to include measures of unit manufacturing cost, quality, inventory turn, speed of new product introduction, flexibility, and delivery dependability (Ferdows and De Meyer, 1990; Filippini et al., 1998; Fine and Hax, 1985; Squire et al., 2006). Within this 
study, the performance of manufacturing processes is assessed and referred to as manufacturing OP, defined as measures of cost, time, quality, and delivery reliability relating to the operations within manufacturing companies. Flexibility was excluded from the study because it is a capability of a manufacturing process and not an operational outcome (Swink and Hegarty, 1998). The rate of new product introduction was also not explored, as it is more dependent on research and development than on the operations organization. Further delimiting this paper, only studies providing empirical evidence of a PC $\rightarrow$ OP relationship in a manufacturing system, supply chain, or manufacturing firm were included for review. This was done to isolate the effects of PC in the absence of managerial interventions.

\subsection{Trade-offs}

The concept of trade-offs is key in discussions of product variety management. Authors have long claimed that it is impossible to succeed in all performance measures simultaneously (Fine and Hax, 1985; Skinner, 1974). However, others have countered this statement, showing that it is possible to achieve high levels of performance across multiple measures (Schonberger, 1986). The trade-off of offering a large product range is the need to balance the increased revenue gained from higher variety with the decreasing unit costs gained from producing or stocking lower variety (Lancaster, 1990). One of the key determinants of the PC $\rightarrow$ OP trade-off is the flexibility of process technology (Zipkin, 2001), with companies in automotive, apparel, and computer industries producing high variety (ElMaraghy et al., 2013; Holweg and Pil, 2005; Zipkin, 2001), and producers of food, textiles, paper, and oil producing less variety (Abdulmalek et al., 2006).

Other known methods for better coping with product variety and complexity include postponement (Forza et al., 2008; Scavarda et al., 2010; Swaminathan and Tayur, 1998; Um, 2017), production scheduling and sequencing (De Groote and Yücesan, 2011; Loveland et al., 2007; Swaminathan and Nitsch, 2007), product architecture, platform, and component commonality (Fisher et al., 1999; Fixson, 2005; Kim and Chhajed, 2000), product modularity (Salvador et al., 2002; Um, 2017), flexible manufacturing systems (Gupta and Goyal, 1992; Handfield and Pagell, 1995), cellular manufacturing (ElMaraghy et al., 2013; Scavarda et al., 2010; Um, 2017; Yeh and Chu, 1991), and product configurators (Trentin et al., 2012).

In examining the $\mathrm{PC} \rightarrow$ OP relationships, this study will review the literature to see if a trade-off exists between the complexity of the assortment produced and the operational performance of the firm. While it is possible that certain OP measures may impact decisions regarding the level of PC in organizations (e.g., determining the product mix that provides the highest throughput on a given production process), this study examines only the unidirectional impact of PC on OP.

This paper is structured as follows: first, the methodology behind the systematic literature review is presented; second, the analysis and coding of the articles are described; third, emerging themes in the literature are discussed; and finally, conclusions are drawn, and future research is suggested.

\section{Methodology}

The systematic literature review approach proposed by Tranfield et al. (2003) was used to perform an unbiased and thorough search of the existing knowledge of the relationships between PC and OP. Systematic literature review has long been an acknowledged method for ascertaining key concepts within scholarly literature in the field of medicine, and it is becoming more widely used in the field of operations management (Burgess et al., 2006; Marasco, 2008; Seuring and Müller, 2008). In contrast with a traditional narrative literature review, systematic literature reviews are designed and reported to ensure replicability and exhaustiveness to reduce bias in the approach (Tranfield et al., 2003). 
A systematic literature review typically consists of three phases: planning, conducting, and reporting (Tranfield et al., 2003). In the planning phase of this study, a search string was developed to explore the body of literature regarding the two constructs of product complexity and manufacturing performance. Two literature databases, Scopus and Web of Science (WoS), were selected because they contain relevant management and engineering journals of high academic quality and cover different sets of journals. Book chapters and conference papers were not included, as the rigor of the peer-review process cannot be guaranteed for these publications.

To ensure a comprehensive and unbiased search, the search string was developed through multiple iterations. The initial search string was constructed in collaboration with four researchers to ensure a broad perspective and reduce the risk of omitting keywords and synonyms. Keywords were added to the search string through an initial literature search until the additional terms did not yield any new results. The search strings used for each database are shown in Table 1 . The search results were limited to journal articles written in English and published within the past 25 years to obtain the most recent research. The basic article data, including title, author name(s), publication name, publication year, and abstract, were extracted from the online WoS and Scopus databases and further processed in a spreadsheet. 
Table 1. Article search strings by database

\begin{tabular}{|c|c|}
\hline Database & Search String \\
\hline $\begin{array}{l}\text { Scopus } \\
\text { (Elsevier) }\end{array}$ & $\begin{array}{l}\text { (TITLE-ABS-KEY (“product complexity” OR “product vari*” OR “product diversi*” OR } \\
\text { "product proliferation” OR “product portfolio complexity” OR “product customi*” OR } \\
\text { “product scope” OR “product hetero*” OR “product mix”) AND TITLE-ABS-KEY } \\
\text { (“performance” OR “time” OR “speed” OR “delivery” OR “dependability” OR “quality” } \\
\text { OR “defect” OR “scrap” OR “rework” OR “reliability” OR “flexibility” OR “productivity” } \\
\text { OR “throughput” OR “efficiency” OR “cost” OR “inventory turn*”)) } \\
\text { AND LANGUAGE (English) AND DOCTYPE (ar) AND PUBYEAR > } 1991 \text { AND TITLE- } \\
\text { ABS-KEY (“production” OR “manufactur*” OR “operation*”) AND (LIMIT-TO } \\
\text { (SRCTYPE, “j”)) }\end{array}$ \\
\hline
\end{tabular}

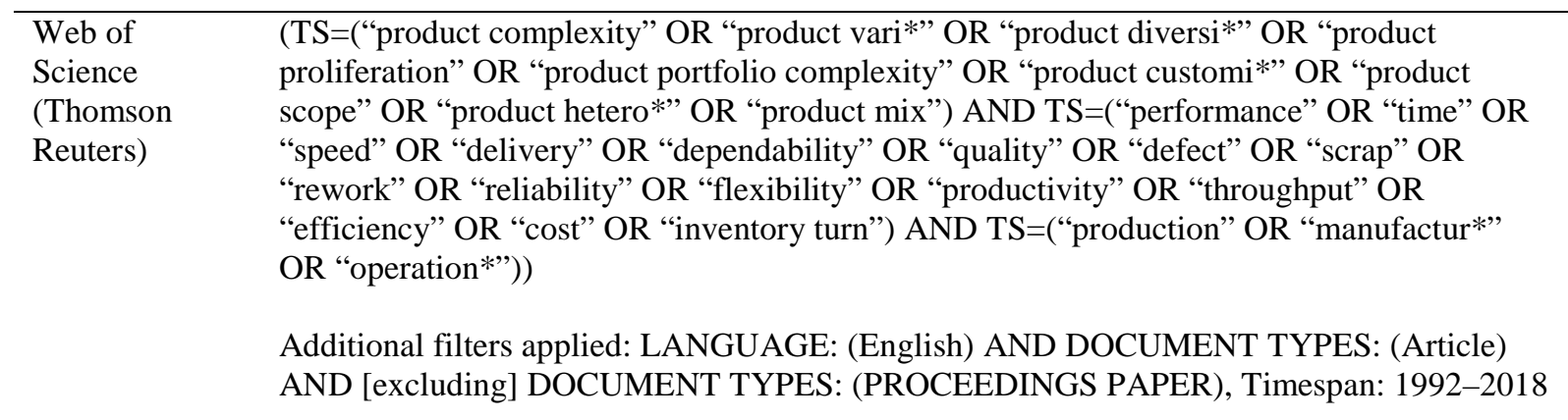

At the beginning of the review, journal quality criteria were applied to the initial sample to narrow the literature and pinpoint the most relevant and thorough studies in the field. The journals must have ranked in the first or second quartile of the Scimago Index in 2015 in operations management or a related field (e.g., engineering or strategy and management) to pass through the quality screening (Scimago Lab, 2017). Duplicate articles arising in both WOS and Scopus were also removed at this step.

Next, abstract criteria were applied to the literature sample to identify articles that utilized the variables PC and OP, as listed in the search string. Only articles that discussed PC and OP as central constructs in a supply chain or manufacturing context within the abstract were assessed for full-text reading. If it was unclear to the authors whether the abstract criteria were met for an article, the article was included for full-text reading to ensure that a reasonable sample size was reached. This screening process resulted in a sample of 284 articles.

A full-text screening was then performed to confirm that each article contained empirical evidence of the relationship between PC and one or more OP measures. To include perspectives from different methodological backgrounds, articles were selected if they had case-based evidence from a qualitative study or numerical evidence from a quantitative study supporting the existence of a PC $\rightarrow$ OP relationship. If the relationship between PC and OP was discussed without offering any empirical evidence, the article was excluded. Similarly, articles were excluded if they studied how an intervention or solution for coping with increased PC more effectively impacted an OP measure. Such articles were abundant in the sample but, if studied, would have shown the impact of the intervention on OP instead of the isolated effect of PC on OP, which was the focus of this study. The study of interventions and their effectiveness is covered in other literature reviews (ElMaraghy et al., 2013; Reis et al., 2013). With regard to quantitative research articles, only relationships between PC and OP which were statistically significant $(\mathrm{p}<0.1)$ were included in the analysis.

The full-text screening resulted in a final sample of 93 articles, which were then analyzed using meta-synthesis, a technique for thematically analyzing and synthesizing literature (Tranfield et al., 
2003). Key variables were coded during the screening, including the PC and OP measures used, the industry and production system type of any case examples in the text, and the direction of any $\mathrm{PC} \rightarrow$ OP relationships found in the text. Meta-analysis was not an option due to the diversity of the literature sample. The thematic synthesis and discussion were focused on the trends seen in the identified PC $\rightarrow$ OP relationships with the purpose of presenting a set of facts rather than building theory (Boer et al., 2015). Additionally, articles showing a quantitative correlation between PC and OP were interpreted as a correlation and not a causation based on the limitations of the methods.

The result of the article screening process is summarized in Figure 1, where an initial search result of 3,101 articles from both databases was reduced to 93 articles for in-depth analysis and coding. The following sections detail the reporting phase of the literature study.

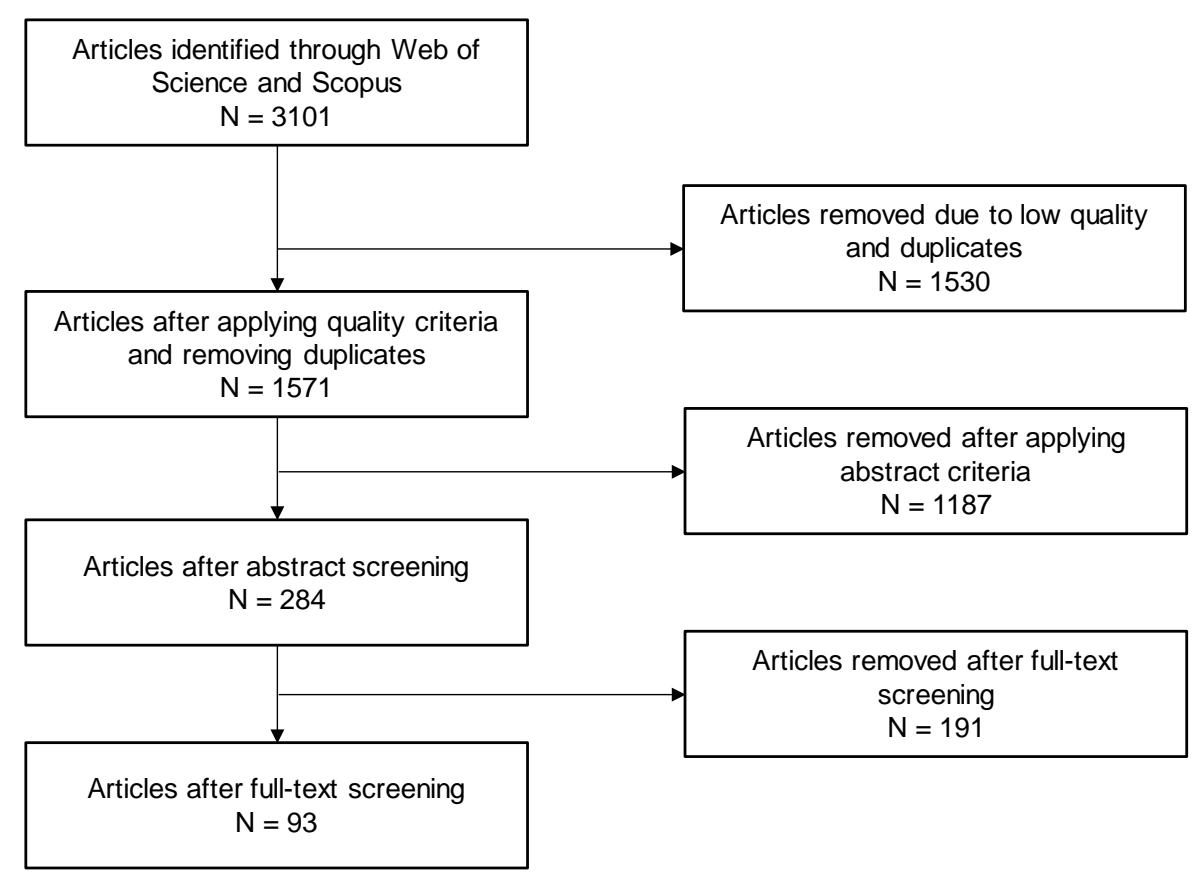

Figure 1. Article selection process

\section{Results}

\subsection{Publication Outlet and Trend}

To understand the demographics of the final literature sample, each of the 93 articles was analyzed by publication date, publication outlet, and industry covered. Furthermore, each article was coded based on the nature of the relationships shown between the measures of PC and OP. As can be seen in Figure 2, there has been a moderate interest in the impact of PC on OP since the mid1990s, with approximately four articles published per year on this topic and peak in publication in 2010. The results are limited to the last 25 years of research due to database restrictions and to cover the most recent research in the area.

Journals publishing studies on the operational impact of PC came from the domains of business strategy and management, operations management, operations research, engineering, and economics. An overview of the journals appearing most frequently in the final article set is shown in Table 2. The six publications in Table 2 reside in the operations management and operations 
research domains, which is logical since the impact of complexity on product and business processes has been a primary concern of top management in recent decades (KPMG, 2011). Apart from the journals in Table 2, approximately 37 other journals were represented in the final article set, with each journal having one or two articles in the sample.

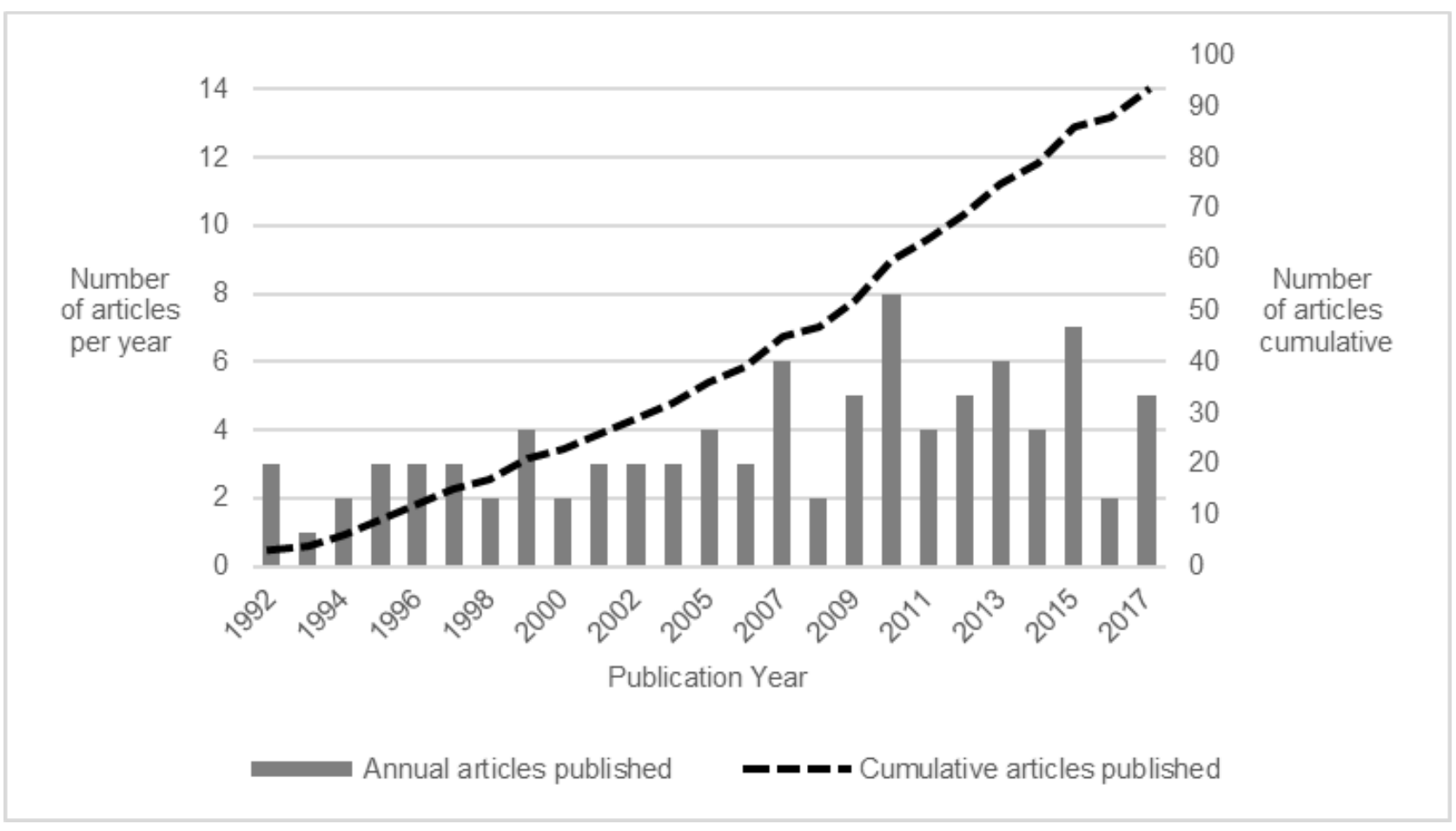

Figure 2. Published articles discussing the relationships between PC and OP, showing the absolute number of articles per year and the cumulative number of articles per year

Table 2. Top publications in the literature search with more than two articles in the final article set

\begin{tabular}{lc}
\hline Publication Name & $\begin{array}{c}\text { Number of } \\
\text { Articles }\end{array}$ \\
\hline International Journal of Production Research & 13 \\
International Journal of Production Economics & 9 \\
International Journal of Operations and Production Management & 8 \\
Management Science & 7 \\
Production and Operations Management & 6 \\
Journal of Operations Management & 6 \\
\hline
\end{tabular}

\subsection{Industry Considered}

The research detailing the PC $\rightarrow$ OP relationship spans a range of industries, as can be seen in Table 3. To classify the industries of the cases and examples used in the articles, the Standard Industrial Classification (SIC) scheme was applied (OSHA, 2017). The articles that used cases or examples to illustrate their purposes were classified using two-digit industry codes. Three-digit codes were not available for the entire set of articles, so the two-digit codes were analyzed instead. 
Articles with four or fewer cases companies appear multiple times in Table 3, with each case company counting as one instance. Articles with five or more companies in the assessed literature sample are counted in the code "Mixed." Articles with no distinct industry group, such as a model of a general flexible manufacturing system, are counted in the group "N/A." To provide a view on the nature of the manufacturing process in each article, the authors categorized the SIC codes as using primarily job shop, batch production, assembly line, manufacturing cells, or continuous flow systems based on the manufacturing system classification of Hayes and Wheelwright (1979).

The results of the industry analysis show a heavy representation of automotive manufacturers, followed by electronics, machinery, and food and beverage manufacturers. Underrepresented in the list are case companies operating with continuous flow processes in process industries, with a minor representation in the food and beverage industry (three cases) along with two chemicals cases, one glass case, and one primary metals case. Process industries typically reside upstream of the supply chain and employ less flexible equipment than assembly systems relying on manual labor (Abdulmalek et al., 2006; Fransoo, 1992).

Table 3. Article case examples grouped by industry code

\begin{tabular}{llc}
\hline SIC Code (two-digit) & Production System & $\begin{array}{l}\text { Number of } \\
\text { Cases }\end{array}$ \\
\hline 37 Transport equipment (cars, motorcycles, bicycles) & Assembly line & 21 \\
36 Electronics (circuit boards) & Assembly line & 10 \\
20 Food and beverage & Continuous \& batch & 9 \\
23 Apparel & Batch production & 3 \\
35 Machinery and equipment (computers, hard drives) & Assembly line & 3 \\
28 Chemicals and allied products & Continuous \& batch & 2 \\
31 Leather Products (Footwear) & Batch production & 2 \\
34 Fabricated Metal Products & Manufacturing cells & 2 \\
22 Textile mill products & Batch production & 1 \\
32 Stone, clay, glass (flat glass) & Continuous & 1 \\
33 Primary metals (rolled steel) & Continuous & 1 \\
39 Miscellaneous (hairbrush producer) & Batch production & 1 \\
47 Transportation services & N/A & 1 \\
50 Trade-durable goods (medical devices) & Assembly line & 1 \\
59 Miscellaneous retail (sporting goods) & Assembly line & 1 \\
Mixed & N/A & 18 \\
N/A & N/A & 22 \\
\hline Note: an article may appear more than once in this list, therefore the sum $>$ 94 articles & \\
\hline
\end{tabular}

Note: an article may appear more than once in this list, therefore the sum $>94$ articles.

\subsection{Measures of PC}

Examining the literature for insights into the $\mathrm{PC} \rightarrow$ OP relationship revealed a range of operationalization for PC measures (see Table 4). The measures used in the literature sample can be organized in five categories: structural PC measures related to product architecture, composite PC measures created with multiple structural PC measures or survey responses, demand distribution measures, production measures, and the degree of product customization. Product variety, measured in terms of the number of end items, or stock keeping units (SKUs), was used most frequently, followed by the number of components. Some variations of PC measures incorporated individual 
product features specific to the analyzed production system, such as model mix and parts complexity for automotive production. Many of the PC measures are detailed variety measures, whereas fewer address the interrelatedness of the components to make it a true complexity indicator (Jacobs, 2013). One economics paper measures PC using the Herfindahl index, which captures the distribution of the demand for a set of products or product segments (Gollop, 1997). Herfindahl indices contain more information in a single value but are less understandable from an operational perspective when examining production systems.

A study by Hu et al. (2008) on product variety-induced manufacturing complexity was added to Table 4 as a measure of PC, although it does not appear in the final article set. This was done because the study presents a concept critical to the discussion of the impact of PC on performance in assembly processes.

\subsection{Measures of $\mathrm{OP}$}

The measures of OP identified in the literature sample were highly fragmented, with over 42 different measures for time, cost, quality, and delivery performance. Due to length restrictions, the final table of OP measures is presented in the Appendix. The OP measures are discussed in the analysis section. 
Table 4. Product complexity (PC) measures identified in the literature sample

\begin{tabular}{|c|c|c|c|}
\hline PC Measure & Definition & Publication & Count \\
\hline \multicolumn{4}{|l|}{ Structural PC measures } \\
\hline Product variants & $\begin{array}{l}\text { The number of finished variants in the } \\
\text { production system and/or offered to the } \\
\text { customer, SKU count in a warehouse or } \\
\text { distribution center, or product line depth, } \\
\text { also referred to as external variety }\end{array}$ & $\begin{array}{l}\text { (Abbey et al., 2013; Abernathy et al., 2000; Ahmad and Shroeder, } \\
\text { 2001; Alford et al., 2000; Alvarez et al., 2016; Anderson, 1995; } \\
\text { Appelqvist et al., 2013; Benjaafar et al., 2004; Berman, 2011; } \\
\text { Berry and Cooper, 1999; Bozarth et al., 2009; Brabazon et al., } \\
\text { 2010; Celano et al., 2012; Cusumano, 1994; Deane and Yang, } \\
\text { 1992; Djassemi, 2005; Engström et al., 1995; Erens and Hegge, } \\
\text { 1994; Gupta and Srinivasan, 1998; Gupta and Goyal, 1992; } \\
\text { Holweg, 2005; Lanza et al., 2010; Mapes et al., 1997; O’Reilly et } \\
\text { al., 2015; Pil and Holweg, 2004; Rajagopalan and Swaminathan, } \\
\text { 2001; Scavarda et al., 2010; Silveira, 1998; Thonemann and } \\
\text { Bradley, 2002; Wan et al., 2012, 2014; Wan and Dresner, 2015; } \\
\text { Wan and Sanders, 2017; Ward et al., 2010; Zhang et al., 2007) }\end{array}$ & 35 \\
\hline Components & $\begin{array}{l}\text { The number of components or the number } \\
\text { of options for a specific component (e.g., } \\
\text { layers on a computer chip, options for } \\
\text { auxiliary parts, number of component } \\
\text { configurations, packaging type) }\end{array}$ & $\begin{array}{l}\text { (Bozarth et al., 2009; Brun and Pero, 2012; Closs et al., 2010; Er } \\
\text { and MacCarthy, 2006; Escobar-Saldívar et al., 2008; Holweg, } \\
\text { 2005; Hsieh and Tong, 2006; Huang and Inman, 2010; Inman and } \\
\text { Blumenfeld, 2014; Kadakia et al., 1994; Keil et al., 2014; Roy et } \\
\text { al., 2011; Sardar and Lee, 2015; Shah et al., 2017; Zhang and } \\
\text { Tseng, 2007) }\end{array}$ & 15 \\
\hline Product families & $\begin{array}{l}\text { The number of product families or product } \\
\text { lines (e.g., car makes and models) }\end{array}$ & $\begin{array}{l}\text { (Moreno and Terwiesch, 2017; Nandkeolyar and Christy, 1992; } \\
\text { Sardar and Lee, 2015; Shah et al., 2017; Wong and Eyers, 2011; } \\
\text { Zhang and Tseng, 2007) }\end{array}$ & 6 \\
\hline Product platforms & The number of product platforms & (Van Den Broeke et al., 2015) & 1 \\
\hline Commonality & The number of similar parts & (Nagarur and Azeem, 1999) & 1 \\
\hline Variety (ranking) & $\begin{array}{l}\text { Product variety, measured as minimal, low, } \\
\text { medium, or high with a survey question }\end{array}$ & (Koh et al., 2005) & 1 \\
\hline $\begin{array}{l}\text { Complexity } \\
\text { (ranking) }\end{array}$ & $\begin{array}{l}\text { Ranking of } 0 \text { to } 1 \text { based on the complexity } \\
\text { of interacting components }\end{array}$ & (Novak and Eppinger, 2001) & 1 \\
\hline Complexity (perceived) & Perceived complexity of the product & (Maruthi and Roshan Joseph, 1999) & 1 \\
\hline \multicolumn{4}{|l|}{ Composite PC measures } \\
\hline $\begin{array}{l}\text { Product complexity } \\
\text { (survey measure) }\end{array}$ & $\begin{array}{l}\text { Varies but aggregates measures of the } \\
\text { number of product families, the number of } \\
\text { components, customization of products, } \\
\text { average parts per BOM, the degree of } \\
\text { modularity, the ability to add new } \\
\text { products, etc. }\end{array}$ & $\begin{array}{l}\text { (Blome et al., 2014; Caniato and Größler, 2015; Christensen et al., } \\
\text { 2007; Eckstein et al., 2015; Hegde et al., 2005; Helkiö and } \\
\text { Tenhiälä, 2013; Koh et al., 2005; Thomé, Sousa and Scavarda do } \\
\text { Carmo, 2014; Tracey, 2004) }\end{array}$ & 9 \\
\hline $\begin{array}{l}\text { Product complexity } \\
\text { (composite) }\end{array}$ & $\begin{array}{l}\text { Composite measure of the number of } \\
\text { attributes, number of variants, weighted by } \\
\text { manufacturing cost, the relative demand of } \\
\text { a product, etc. }\end{array}$ & $\begin{array}{l}\text { (Anderson, 1995; Ding et al., 2007; Sun and Ding, 2010; Vilas } \\
\text { and Vandaele, 2002) }\end{array}$ & 4 \\
\hline Model mix complexity & $\begin{array}{l}\text { Function of the number of car models, } \\
\text { body types, models; also corrects for the } \\
\text { number of assembly lines per plant }\end{array}$ & (Ittner and MacDuffie, 1995; MacDuffie et al., 1996) & 2 \\
\hline Parts complexity & $\begin{array}{l}\text { Function of the number of engine } \\
\text { transmissions, wire harnesses, exterior } \\
\text { paint colors, suppliers, parts in assembly, } \\
\text { and percentage of common parts }\end{array}$ & (Ittner and MacDuffie, 1995; MacDuffie et al., 1996) & 2 \\
\hline Options variability & $\begin{array}{l}\text { Standard deviation in the number of } \\
\text { options per car for } 8 \text { key options }\end{array}$ & (Fisher and Ittner, 1999; MacDuffie et al., 1996) & 2 \\
\hline Options content & $\begin{array}{l}\text { Average number of options per car in each } \\
\text { month }\end{array}$ & $\begin{array}{l}\text { (Fisher and Ittner, 1999; Ittner and MacDuffie, 1995; MacDuffie } \\
\text { et al., 1996) }\end{array}$ & 3 \\
\hline \multicolumn{4}{|l|}{ Demand distribution } \\
\hline Product mix skewness & $\begin{array}{l}\text { The distribution of demand across } \\
\text { products, where low skewness represents } \\
\text { equally distributed demand across products } \\
\text { and extreme skewness represents demand } \\
\text { concentrated on a few variants }\end{array}$ & $\begin{array}{l}\text { (Akkerman and van Donk, 2007; Jensen et al., 1996; Ruiz-Torres } \\
\text { and Mahmoodi, 2007, 2008, Seifoddini and Djassemi, 1996, } \\
\text { 1997) }\end{array}$ & 6 \\
\hline Herfindahl type & $\begin{array}{l}d=1-\sum_{i} s_{i}^{2}+\sum_{i} \sum_{k \neq i} s_{i} s_{k} \sigma_{i k} \text {, where } \\
s_{i} \text { is the share of sales from product } i \text { and } \\
k, \text { and } \sigma_{i k} \text { is a distance function between } \\
\text { products } i \text { and } k \text {, or similar variation }\end{array}$ & $\begin{array}{l}\text { (Aw and Lee, 2009; Brahm et al., 2017; Gollop, 1997; Vachon } \\
\text { and Klassen, 2002) }\end{array}$ & 4 \\
\hline Entropy index & $\begin{array}{l}\sum_{p=1}^{n} s_{p} * \ln \left(\frac{1}{s_{p}}\right) \text {, where } s_{p} \text { is the share of } \\
\text { sales for product } p\end{array}$ & (Baldwin et al., 2012; Thirumalai and Sinha, 2011) & 2 \\
\hline Demand interrelatedness & $\begin{array}{l}\text { Correlation of the demand between } \\
\text { products and packaging type }\end{array}$ & (Akkerman and van Donk, 2009) & 1 \\
\hline
\end{tabular}


Table 4. Product complexity (PC) measures identified in the literature sample (continued)

\begin{tabular}{|c|c|c|c|}
\hline PC Measure & Definition & Publication & Count \\
\hline \multicolumn{4}{|c|}{ Production measures } \\
\hline Batch size & $\begin{array}{l}\text { Production run length used as an indicator of } \\
\text { variety }\end{array}$ & $\begin{array}{l}\text { (Berry and Cooper, 1999; Celano et al., 2012; Nazarian et } \\
\text { al., 2010) }\end{array}$ & 3 \\
\hline Setups & The number of setups as an indicator of variety & (Anderson and Sedatole, 2012; Yang and Deane, 1993) & 2 \\
\hline $\begin{array}{l}\text { Product variety- } \\
\text { induced } \\
\text { manufacturing } \\
\text { complexity }\end{array}$ & $\begin{array}{l}\text { Measures of the information entropy at a } \\
\text { workstation due to the choice of components, tools, } \\
\text { work procedures, etc. }\end{array}$ & (Busogi et al., 2017; Hu et al., 2008) & 2 \\
\hline \multicolumn{4}{|c|}{ Degree of customization } \\
\hline $\begin{array}{l}\text { Degree of } \\
\text { customization } \\
\text { (survey) }\end{array}$ & $\begin{array}{l}\text { Survey aggregate responses on the customization } \\
\text { levels of products }\end{array}$ & $\begin{array}{l}\text { (Ahmad and Shroeder, 2001; Bortolotti et al., 2013; Bozarth } \\
\text { et al., 2009; Hegde et al., 2005; Rosenzweig, 2009; Squire et } \\
\text { al., 2006) }\end{array}$ & 6 \\
\hline $\begin{array}{l}\text { Degree of } \\
\text { customization }\end{array}$ & $\begin{array}{l}\text { The degree to which the customer is involved in } \\
\text { the production process, ranking, and other }\end{array}$ & $\begin{array}{l}\text { (Akinc and Meredith, 2015; Wong and Eyers, 2011; Wong } \\
\text { and Lesmono, 2013; Xia and Rajagopalan, 2009) }\end{array}$ & 4 \\
\hline
\end{tabular}

\subsection{Analysis of PC $\rightarrow O P$ Relationships}

Every relationship between PC and OP identified through the full-text literature review and coding was mapped, with the collective work summarized in Table 5. The relationships received a primary code based on the detailed OP measure used and a secondary code based on the direction of the relationship: positive, no relationship, negative, U-shape, inverted U-shape, and other relationship. Positive relationships between PC and OP were defined as being beneficial for business performance, meaning increasing time-based performance (e.g., increased throughput or efficiency, decreased cycle time, decreased lead time), decreasing cost, increasing quality or decreasing rework, and increasing delivery reliability. Negative relationships imply a detrimental relationship between PC and OP. The category "no relationship" was included to categorize the articles that tested relationships but reported them as non-significant. Examples supporting the $\mathrm{PC} \rightarrow \mathrm{OP}$ relationships shown in Table 5 are discussed below.

Table 5. Relationships identified in full-text readings between product complexity (PC) and operational performance $(\mathrm{OP})$ measures

\begin{tabular}{|c|c|c|c|c|c|c|}
\hline OP Measure & $\begin{array}{c}\text { Positive } \\
\text { relationship }\end{array}$ & $\begin{array}{c}\text { No } \\
\text { relationship }\end{array}$ & $\begin{array}{c}\text { Negative } \\
\text { relationship }\end{array}$ & $\begin{array}{c}\text { U- } \\
\text { shape }\end{array}$ & $\begin{array}{l}\text { Inverted } \\
\text { U-shape }\end{array}$ & Other \\
\hline \multicolumn{7}{|l|}{ Costs } \\
\hline $\begin{array}{l}\text { Operations costs } \\
\text { (general) }\end{array}$ & 1 & 4 & 16 & 2 & 1 & \\
\hline Direct labor costs & 1 & 5 & 3 & & & \\
\hline $\begin{array}{l}\text { Manufacturing } \\
\text { overhead costs }\end{array}$ & & 4 & 5 & & & \\
\hline Inventory costs & 1 & 2 & 12 & 1 & & \\
\hline \multicolumn{7}{|l|}{ Time } \\
\hline Lead time & 1 & 4 & 14 & 2 & & \\
\hline Processing time & 1 & 3 & 14 & & 1 & \\
\hline Setup time & & & 10 & & & \\
\hline Productivity & & 1 & 7 & & 1 & 1 \\
\hline Quality & & 10 & 12 & & 1 & 2 \\
\hline Delivery & 2 & 9 & 11 & 2 & & \\
\hline
\end{tabular}




\subsection{PC is related to increasing operations and inventory costs, but no impact on labor}

3.6.1 General manufacturing costs. There are numerous articles supporting the claim that increased PC leads to increased manufacturing and supply chain costs (Alford et al., 2000; Berman, 2011; Bozarth et al., 2009; Ding et al., 2007; Lanza et al., 2010; Mapes et al., 1997; Moreno and Terwiesch, 2017; Roy et al., 2011; Sardar and Lee, 2015; Silveira, 1998; Squire et al., 2006; Sun and Ding, 2010; Thonemann and Bradley, 2002; Wan and Dresner, 2015; Wong and Eyers, 2011; Zhang and Tseng, 2007). Most of these studies suggest a linear relationship between the number of finished products or product families produced and operations costs.

Two articles identified an inverted U-shaped relationship between PC and operations costs (Wan, 2016; Wan and Dresner, 2015), meaning that increasing PC becomes less costly the more PC a firm produces, up until the point that costs decrease with added PC. Both studies identifying this relationship were performed in soft-drink bottling facilities, with one study examining a measure of pack size variety (Wan, 2016) and the other examining the total SKUs produced (Wan and Dresner, 2015). One explanation for the inverted U-shaped relationship is that variety can be added in a way that has minimal impact on the production system. For example, a soft-drink company with a standard pack size of 12 units adding a new packing variant of 24 units would incur less additional operations and logistics costs than if they were to add a new packing variant of 30 units, presuming that the packaging of the 12- and 24-unit variants was similar (Wan, 2016). The author argued that "with higher pack-size variety, different packs are more likely to have similar shapes and size," thus, supporting a concave curvilinear relationship (Wan, 2016, p. 273).

In contrast, a U-shaped relationship was identified by Van Den Broeke et al. (2015), who studied the relationship between the number of product platforms and total supply chain costs, showing that too few platforms lead to high customization costs to make the end products unique, while too many platforms (e.g., one platform per product line) lead to a higher purchasing price for the platform due to the lower quantity ordered.

Four survey studies identified no relationship between operations costs and the number of components, degree of product customization, and composite measures of product complexity (Bortolotti et al., 2013; Bozarth et al., 2009; Caniato and Größler, 2015; Helkiö and Tenhiälä, 2013).

Only one study found that higher PC led to lower manufacturing costs (Eckstein et al., 2015). Eckstein et al. (2015) measured PC as an aggregated result of responses to survey questions about the number of product components, number of new variants, customization degree, and value-added services. Cost performance was a survey measure based on the costs of manufacturing, inventory, transportation, handling, and purchased goods. This direct effect was found when building a preliminary model to test the moderating effect of product complexity on the effect of supply chain adaptability on cost performance (Eckstein et al., 2015). However, the authors did not explain the reason for the positive impact of PC on cost performance in the preliminary model.

3.6.2 Direct labor. In assessing the impact of PC on direct labor, the results are mixed across three automotive studies (Fisher and Ittner, 1999; Ittner and MacDuffie, 1995; MacDuffie et al., 1996). Since many PC measures are used, each having unique impacts on direct labor costs, a summary of the relationships is presented in Table 6 . The studies show that parts complexity consistently increases direct labor costs (negative relationship) while model mix complexity does not impact direct labor hours. Measures of options complexity and variability show mixed results. Possible reasons for the lack of a relationship between model mix and options-related PC measures are the placement of slack labor at workstations with high PV (Fisher and Ittner, 1999), the presence of 
lean capabilities (MacDuffie et al., 1996), production line design for mixed model assembly (MacDuffie et al., 1996), and options bundling (Ittner and MacDuffie, 1995). The counter-intuitive finding that options variability decreases direct labor costs was particularly surprising to the study's authors, who suggest that the correlation could be linked to the capability of the analyzed manufacturing plants to handle a high product mix (MacDuffie et al., 1996).

Table 6. Impact of specific PC measures on direct labor costs (grey indicates N/A)

\begin{tabular}{lccc}
\hline PC Measure & $\begin{array}{c}\text { Ittner et al. } \\
(\mathbf{1 9 9 6 )}\end{array}$ & $\begin{array}{c}\text { MacDuffie et al. } \\
\mathbf{( 1 9 9 6 )}\end{array}$ & $\begin{array}{c}\text { Fisher \& Ittner } \\
\text { (1999) }\end{array}$ \\
\hline Model mix complexity & no rel & no rel & \\
Parts complexity & - & - & \\
Options content/complexity & no rel & - & no rel \\
Options variability & & + & no rel \\
\hline
\end{tabular}

3.6.3 Manufacturing overhead costs. The relationships between PC and measures of manufacturing overhead (MOH) costs, such as indirect labor and fixed manufacturing expenses, are summarized in Table 7. Articles finding an increase in $\mathrm{MOH}$ costs with increased PC (negative relationship in this study) were focused on automotive firms (Fisher and Ittner, 1999; Ittner and MacDuffie, 1995; Scavarda et al., 2010), household appliance firms (Brun and Pero, 2012), textile manufacturers (Anderson, 1995), and a float glass manufacturer (Anderson and Sedatole, 2012). In a study of three textile plants, only three of seven attributes were found to be negatively related with $\mathrm{MOH}$, with different variety measures being statistically significant in each plant, while the other four had no relationship with $\mathrm{MOH}$ (1995). According to the author, "this research demonstrates that, at least in some environments, attribute-based measures of [product complexity] achieve their objective of providing improved estimation and greater understanding of $[\mathrm{MOH}]$ and its drivers" (Anderson, 1995, p. 382). One of the key findings of these articles is that specific PC measures significantly impact $\mathrm{MOH}$ in each industry and factory context, making it difficult to generalize the $\mathrm{PC} \rightarrow \mathrm{MOH}$ relationship across studies.

One set of authors elucidated the $\mathrm{PC} \rightarrow \mathrm{MOH}$ relationship with a few key sentences, stating, "With an increasingly complex product mix comes additional parts, greater inventory and material handling, additional setups, more complex scheduling and task assignment, and increased supervisory requirements” (Ittner and MacDuffie, 1995, p. 315), with the mentioned effects falling under MOH costs. Another perspective is given by Scavarda et al. (2010), who found that PC offered to the market can create more $\mathrm{MOH}$ in emerging markets due to the need for increased training time (Scavarda et al., 2010). This reveals the importance of the country context and market maturity when assessing the $\mathrm{PC} \rightarrow$ OP relationship. 
Table 7. Impact of specific PC measures on manufacturing overhead costs (grey indicates N/A)

\begin{tabular}{|c|c|c|c|c|c|c|}
\hline PC Measure & $\begin{array}{c}\text { Ittner et al. } \\
\text { (1996) }\end{array}$ & $\begin{array}{c}\text { Fisher \& } \\
\text { Ittner } \\
\text { (1999) }\end{array}$ & $\begin{array}{l}\text { Scavarda et } \\
\text { al. (2010) }\end{array}$ & $\begin{array}{c}\text { Anderson \& } \\
\text { Sedatole } \\
(2012)\end{array}$ & $\begin{array}{l}\text { Brun \& Pero } \\
\text { (2012) }\end{array}$ & $\begin{array}{c}\text { Anderson } \\
\text { (1995) }\end{array}$ \\
\hline Number of variants & & & - & & & (no rel) \\
\hline Component options & & & & & - & \\
\hline $\begin{array}{l}\text { Model mix } \\
\text { complexity }\end{array}$ & no rel & & & & & \\
\hline Parts complexity & - & & & & & \\
\hline $\begin{array}{l}\text { Options content/ } \\
\text { complexity }\end{array}$ & - & no rel & & & & \\
\hline Options variability & & - & & & & \\
\hline Number of setups & & & & no rel & & \\
\hline Textile factors & & & & & & $(3$ of 7$)$ \\
\hline
\end{tabular}

Four studies in the literature set found no relationship between specific measures of product variety and $\mathrm{MOH}$. In the automotive sector, the complexity of main models had no relation to $\mathrm{MOH}$ because model variety primarily affects the body shop and not the final assembly stage of car manufacturing (Ittner and MacDuffie, 1995). The options content (or number of options) per car on a production line showed no significant relationship with $\mathrm{MOH}$; it was the variation in options content created by both demand variation and production scheduling that proved to have a greater effect on operations, complicating production scheduling (Fisher and Ittner, 1999). The third study of a float glass manufacturer found that the number of setups (a proxy measures of product variety) has no relationship with monthly $\mathrm{MOH}$, which the authors attributed to the high level of automation minimizing the need for surplus manning during changeovers (Anderson and Sedatole, 2012).

3.6.4 Inventory Costs. The impact of PC on inventory costs was found to be detrimental in eleven cases within the literature sample, where inventory costs increase as PC increases (Abbey et al., 2013; Abernathy et al., 2000; Benjaafar et al., 2004; Escobar-Saldívar et al., 2008; Fisher and Ittner, 1999; Moreno and Terwiesch, 2017; O’Reilly et al., 2015; Pil and Holweg, 2004; Rajagopalan and Swaminathan, 2001; Seifoddini and Djassemi, 1996; Wan and Sanders, 2017; Ward et al., 2010). The predominant PC measure used in the inventory literature was the number of products in the system or in the product line. Many companies keep stock of each finished product variant to improve lead times and service levels for the customer. Thus, if the number of product variants increases, it is logical to assume that inventory levels and cost will also increase. This relationship has been found to be largely linear (Benjaafar et al., 2004; Moreno and Terwiesch, 2017; Wan and Sanders, 2017), although there is evidence of a U-shaped relationship between PC and inventory costs (Brabazon et al., 2010).

Other factors affecting the PC $\rightarrow$ inventory cost relationship identified in the literature are the stocking strategy and forecast bias. First, Pil and Holweg (2004) explained that if a company builds to stock or builds to forecast, more variants will be held in inventory, and inventory costs will rise. However, if a firm builds to order and keeps no finished stock, the relationship of PC with 
inventory costs will not be negative unless the firm needs to keep a significantly higher number of components and work in process inventory. Second, Wan and Sanders (2017) showed that the number of SKUs affected inventory levels through forecast bias in a distribution center for beverages. Furthermore, they demonstrated that vertical integration of the supply chain lessens the impact of PC on inventory levels.

Two instances emerged where PC had no relationship with inventory costs in automotive plants (Appelqvist et al., 2013; Fisher and Ittner, 1999). The lack of a relationship between options content and inventory costs was not explained by Fisher and Ittner (1999). However, in a case study of decreasing product variants in a sporting goods manufacturer, Appelqvist et al. (2017) found that many of the products that were removed were not being sold, and therefore the reduction did not affect inventory levels. The single article finding a positive relationship between the number of car makes and inventory costs was that of Moreno and Terwiesch (2017), although the coefficient was not very large and the authors did not offer a causal explanation.

\subsection{PC is related to increasing lead time, processing time, setup time, and decreasing productivity}

3.7.1 Lead time. Product complexity was related to increasing lead time (negative relationship with respect to performance) in fourteen examples within the literature sample (Akinc and Meredith, 2015; Akkerman and van Donk, 2009; Berman, 2011; Feng et al., 2011; Holweg, 2005; Inman and Blumenfeld, 2014; Mapes et al., 1997; Squire et al., 2006; Thonemann and Bradley, 2002; Vilas and Vandaele, 2002; Ward et al., 2010; Wong and Lesmono, 2013; Xia and Rajagopalan, 2009; Zhang et al., 2007). The negative PC $\rightarrow$ lead time relationships identified in the literature sample were linear (Mapes et al., 1997; Zhang et al., 2007), concave, and increasing as an exponential function (Thonemann and Bradley, 2002). Two U-shaped relationships were found in a simulation study of the number of product variants of an automobile manufacturer (Brabazon et al., 2010) and in a study on the product mix skewness of a food producer (Akkerman and van Donk, 2007).

Zhang and Chen (2007) provided evidence for both a "negative relationship" and a "no relationship" classification (Table 5), where an increasing number of base models in an automotive factory is related to increasing lead time, while the average number of car types per model (e.g., body, engine) is not related to lead time. Three other articles identified no relationship between PC and lead time (Caniato and Größler, 2015; Christensen et al., 2007; Vachon and Klassen, 2002), all of which involved large sample populations and utilized survey-based measures of PC and lead time.

One study in the literature sample identified a positive relationship between PC and lead time (Gupta and Srinivasan, 1998). Applying queuing theory and using order backlog as a proxy measure for lead time, Gupta and Srinivasan (1998) demonstrated that total backlog can decrease with increasing product variants if the production rates are adjusted across the products and the utilization of the factory is kept constant. Furthermore, the authors stated that if factory utilization increases with increasing PC and no processing time adjustments are made to stabilize factory utilization, it is likely that the backlog and lead time will increase. This relationship was coded as positive because the management interventions of adjusting production rates and utilization were seen to fall within daily operations management activities and not as extreme changes in production strategy (e.g., investing in flexible technology, reconfiguring the supply chain).

Increasing the number of product variants in operations can cause complexity in production, increase the likelihood of errors due to an increased number of transactions, increase the risk of a disruption to the supply chain (e.g., a supplier's failure to deliver critical components), create unplanned delays, and increase the overall lead time to the customer (Inman and Blumenfeld, 2014; Jacobs and Swink, 2011; Mapes et al., 1997). It was also found that increased lead times could be 
due to increased order processing time but not increased manufacturing processing time (Zhang et al., 2007).

Variability in demand resulting from high product variety was also shown to be a key factor in the PC $\rightarrow$ lead time relationship. Vilas and Vandaele (2002) found that lead time increased as the variety within a manufacturing system became more differentiated or skewed in production times, setup times, and batch sizes such that one product form was notably higher in these dimensions than the others. Increased demand correlation between products was shown to increase lead times in a food processing company because of the resulting imbalance in the production system, which increased the machine blockage and starvation times (Akkerman and van Donk, 2009).

A further moderating factor mentioned in the literature was the choice of the customer order decoupling point. Two papers argued that the choice of the customer order decoupling point also affects lead time when comparing firms; for example, an engineer-to-order firm will have longer lead times than an assemble-to-order firm (Akinc and Meredith, 2015; Holweg, 2005). Product customization will automatically create a longer lead time than standard products due to the extra time needed to design or configure the product, as can be seen in the lead times for custom Levi's blue jeans and other garments (Xia and Rajagopalan, 2009).

\subsubsection{Processing time. Assessing the impact of PC on processing time in various manufacturing} contexts led to mixed results, with fourteen articles finding evidence of a negative relationship (increasing processing time, queuing time, job waiting time, machine flow time, order tardiness, etc.) (Busogi et al., 2017; Djassemi, 2005; Engström et al., 1995; Er and MacCarthy, 2006; Gupta and Goyal, 1992; Jensen et al., 1996; Keil et al., 2014; Nagarur and Azeem, 1999; Nazarian et al., 2010; Ruiz-Torres and Mahmoodi, 2008, 2007, Seifoddini and Djassemi, 1996, 1997; Yang and Deane, 1993), three articles finding evidence of no relationship (Er and MacCarthy, 2006; Vachon and Klassen, 2002; Zhang et al., 2007), and one article finding a positive relationship (Ruiz-Torres and Mahmoodi, 2007). The one instance of a positive PC $\rightarrow$ processing time relationship occurred for a flexible manufacturing shop where cells designed to produce more product families had an improved processing time with a more extreme product mix (Ruiz-Torres and Mahmoodi, 2007).

A few of the factors moderating the PC $\rightarrow$ processing time relationship are the flexibility of the manufacturing system, the skill level of the workforce, and the criticality of components being diversified. Regarding machine flexibility, product mix variability was shown to have a greater impact on cell shops than on job shops, which are known for their flexibility (Jensen et al., 1996). Similarly, factories with dedicated manufacturing cells designed to produce one product family had increased processing times under a more extreme product mix (Ruiz-Torres and Mahmoodi, 2007). Regarding skill level, adding cross-functional workforce reduced the effect of added variety in both cellular manufacturing and job shops (Djassemi, 2005). Er and MacCarthy (2006) appear in both the "negative relationship" and "no relationship" categories, as they found that individual types of variety in manufacturing influence processing time differently. As the number of critical materials in an upstream manufacturing process increases from 1 to 5 , the flow time increases $29 \%$ due to the additional setups and material shortages, which cause production to stop. Contrastingly, the authors found that downstream variety in terms of the amount of packaging materials was not related to processing time, as the packaging materials were not as critical.

One of the most discussed mediation variables between PC and OP is product variety-induced manufacturing complexity (PVIMC), or the information entropy provided to an operator at a workstation that affects his or her choice of components, tools, fixtures, and work procedures (Hu et al., 2008; Zeltzer et al., 2013). While six articles discussing PVIMC appeared in the full-text screening phase of the literature study, only one of these articles included empirical evidence for the relationship between PVIMC and OP. Busogi et al. (2017) demonstrated that having many similar 
yet unique components in a workstation increases the choice complexity and the reaction time needed to distinguish between components and select the appropriate one.

3.7.3 Setup Time. While it is possible to logically deduce the impact of PC on setup times (greater variety produced in the same amount of time increases product changeovers), ten articles in the final literature set contained empirical evidence of this in apparel, chemicals, household appliance, sheet metal, automobile, street scooter, and generic manufacturing systems as well as in mass manufacturing surveys (Anderson, 1995; Baldwin et al., 2012; Berry and Cooper, 1999; Brun and Pero, 2012; Celano et al., 2012; Cusumano, 1994; Escobar-Saldívar et al., 2008; Kampker et al., 2012; Sardar and Lee, 2015; Vilas and Vandaele, 2002). No articles were found suggesting a positive relationship (decreasing setup time) or an absence of a relationship between the variables in question.

3.7.4 Productivity. Product variety led to decreased process productivity in every article that studied the PC $\rightarrow$ productivity relationship (Anderson and Sedatole, 2012; Aw and Lee, 2009; Berry and Cooper, 1999; Gollop, 1997; Nagarur and Azeem, 1999; Nandkeolyar and Christy, 1992; Silveira, 1998). Decreased productivity due to PC occurs due to the reduced line speeds, increased downtime, and increased number of process adjustments that come with producing a higher variety of products, especially on process lines (Berry and Cooper, 1999). However, more flexible processes do not experience the same loss in productivity with increasing variety (Nandkeolyar and Christy, 1992). A further contingency variable related to the effect of PC on process productivity is the sequencing of production orders, where short orders planned in an optimal sequence show no negative impact on process productivity (Berry and Cooper, 1999).

One study showing a lack of relationship between PC and productivity looked at the effect of adding, dropping, or maintaining products on the total factor productivity of 3330 Chilean manufacturing plants. Companies that only added products showed no statistically significant changes in total factor productivity, but firms that added new products and dropped products in the same year increased total factor productivity compared to companies that did not change product variety or only added or dropped products (Alvarez et al., 2016). This study gives weight to the portfolio review process and the "one-in, one-out” rule for managing product portfolios.

An inverted U-shaped relationship was identified between PC (Herfindahl type index) and productivity (i.e., the natural logarithm of average drop size) in a transportation company (Brahm et al., 2017). One of the mechanisms at play in the study was operational friction, which is created by adding a variety that is dissimilar from the variety currently being offered (e.g., adding a confectionary product line when the company mostly produces beverages). This friction takes the form of modified work routines, increased communication, and a need to manage interdependencies in the business, all of which can erode productivity. However, the authors found evidence that these operational frictions could be reduced with more worker experience (Brahm et al., 2017).

\subsection{PC $\rightarrow$ Unclear effect on quality performance}

The literature investigating the impact of PC on quality measures, such as the rework percentage, repair costs, error rate, and inspection costs, was equally distributed between the "no relationship" and "negative relationship" classifications. Articles finding a negative relationship between PC and quality measures assessed the impact of detailed variety measures, such as options variability, plant build complexity, the number of component options, run length, and the degree of customization (Berman, 2011; Brun and Pero, 2012; Celano et al., 2012; Fisher and Ittner, 1999; Hegde et al., 2005; Huang and Inman, 2010; Mapes et al., 1997; Maruthi and Roshan Joseph, 1999; Novak and Eppinger, 2001; Shah et al., 2017; Silveira, 1998; Thirumalai and Sinha, 2011). The line of 
reasoning for the negative $\mathrm{PC} \rightarrow$ quality relationship is that a higher number of products impedes operational focus, resulting in manufacturing errors, order mismatches, and rework (Shah et al., 2017). In process industries, increased variety leads to small batches, which result in increased inspection costs due to the inability to adequately determine a steady-state mean and standard deviation for the process (Celano et al., 2012). Novak and Eppinger (2001) found that the negative $\mathrm{PC} \rightarrow$ quality relationship is moderated by the make/buy decisions of the firm. Further, they provided case evidence suggesting that companies that outsource complex components receive lower quality components than those that make the more complex components in-house.

Articles that found no PC $\rightarrow$ quality relationship mostly employed composite PC measures (e.g., options content, model mix, and survey PC measures) (Caniato and Größler, 2015; Fisher and Ittner, 1999; Helkiö and Tenhiälä, 2013; MacDuffie et al., 1996; Mapes et al., 1997; Shah et al., 2017; Squire et al., 2006; Thomé, Sousa and Scavarda do Carmo, 2014). One explanation that was given for the lack of a $\mathrm{PC} \rightarrow$ quality relationship was the impact of relentless focus on improving quality for manufacturers in OECD countries in the 1980s (Squire et al., 2006).

The degree of customization PC measure was a subject of disagreement in the literature sample. Squires et al. (2006) found no relationship between customization and quality, while Hegde et al. (2005) found support for both a negative, linear relationship and an inverted U-shaped relationship. Looking closer at the studies, Hegde et al. (2005) performed a regression analysis of 322 iron and steel foundries, whereas Squire et al. (2006) used an analysis of variance methods to examine 102 UK manufacturing industries, with a specific focus on firms affected by mass customisation. The exact reason for the differing results is unknown, but it could be related to the difference in the industry domains and the methods of operationalizing PC and quality variables in their large data sets.

Two articles in the sample did not fit into a classification in Table 5, as they developed specific mathematical relationships to predict the yield of an integrated circuit (IC) board and multi-chip module process based on specific product features, such as the product surface area and number of layers (Hsieh and Tong, 2006; Kadakia et al., 1994). These are two of three articles in the literature sample discussing the impact of PC on yield for IC manufacturers.

\subsection{PC $\rightarrow$ Unclear effect on delivery performance}

The discussion surrounding the relationship between PC and measures of delivery performance was roughly equally split between "no relationship" and "negative relationship," with a few exceptions. Articles categorized as showing a negative relationship included assessments of unit and order fill rates (Closs et al., 2010; Mapes et al., 1997; Wan et al., 2012, 2014) and delivery reliability and responsiveness (Ahmad and Shroeder, 2001; Appelqvist et al., 2013; Jensen et al., 1996; Koh et al., 2005; Mapes et al., 1997; Rosenzweig, 2009; Ruiz-Torres and Mahmoodi, 2008). A few of these cases were linear in nature (Ahmad and Shroeder, 2001; Appelqvist et al., 2013; Closs et al., 2010; Wan et al., 2014). Increasing PC in manufacturing and supply chains can increase the uncertainty in product demand (Koh et al., 2005) as well as in the number of decisions made by a company towards suppliers, customers, and competitors, increasing the time needed to coordinate activities (Ahmad and Shroeder, 2001) and the likelihood of errors in the value chain, including delivery errors (Mapes et al., 1997).

Two cases of a U-shaped relationship between PC and delivery performance were identified in a study examining the number of products of a beverage distributor (Wan et al., 2012, 2014). Wan, Evers, and Dresner (2012) modeled the relationship between SKUs and fill rate as a convex and decreasing U-shape with the inflection point, or threshold product variety level, being outside of the feasible range. The authors tested this relationship with the idea that adding variety at low variety levels, when products tend to have greater dissimilarity, hinders delivery performance more than at 
high levels of variety, when products are more similar to each other (Wan et al., 2012). The number of products per line had a U-shaped relationship with the order fill rate (Wan et al., 2014). This relationship likely results from difficulties in forecasting demand and managing inventory at distribution centers. One explanation for this marginal effect is that high similarities exist between new products and existing products when product line variety is already high, which could reduce the negative operational impact.

Articles classified as having no PC $\rightarrow$ delivery performance relationship mostly utilized composite PC measures based on survey results and the degree of product customization (Ahmad and Shroeder, 2001; Appelqvist et al., 2013; Bortolotti et al., 2013; Caniato and Größler, 2015; Eckstein et al., 2015; Helkiö and Tenhiälä, 2013; Koh et al., 2005; Squire et al., 2006; Thomé, Sousa and do Carmo, 2014; Vachon and Klassen, 2002). One of the explanations for the lack of a relationship between product customization and delivery performance is that many firms offering a high variety of products employ methods such as variety reduction, modularity, and mass customization, which can moderate the negative effects of product customization (Bortolotti et al., 2013), thus making the effect of high PC less visible.

As for the two positive PC $\rightarrow$ delivery relationships, PC led to higher outbound transport effectiveness and delivery service in a survey of 180 manufacturing firms (Tracey, 2004) and decreased backlog in a make-to-order manufacturing system (Gupta and Srinivasan, 1998). The authors of the first article did not explain their results, while the results of the second study are partially due to the regulation of product demand as variety increases.

\section{Discussion}

Based on the literature coding and analysis, it can be concluded that the overarching relationship between PC and OP is negative. The literature coding and analysis summarized in Table 5 revealed that cost and time OP measures were studied more frequently than quality and delivery measures. The negative impact of PC on general operations costs, inventory costs, lead time, processing time, setup time and productivity are the most conclusive relationships identified in the cost section of this study, showing high agreement amongst scholars. Utilizing the five categories of product complexity measures and the results from the coding analysis, Figure 3 was constructed to display the PC $\rightarrow$ OP relationships where a clear negative linear, U-shaped, or inverted U-shaped relationship was identified. Structural PC measures were the most researched, and thereby, had some of the most conclusive relationships with different OP measures. 


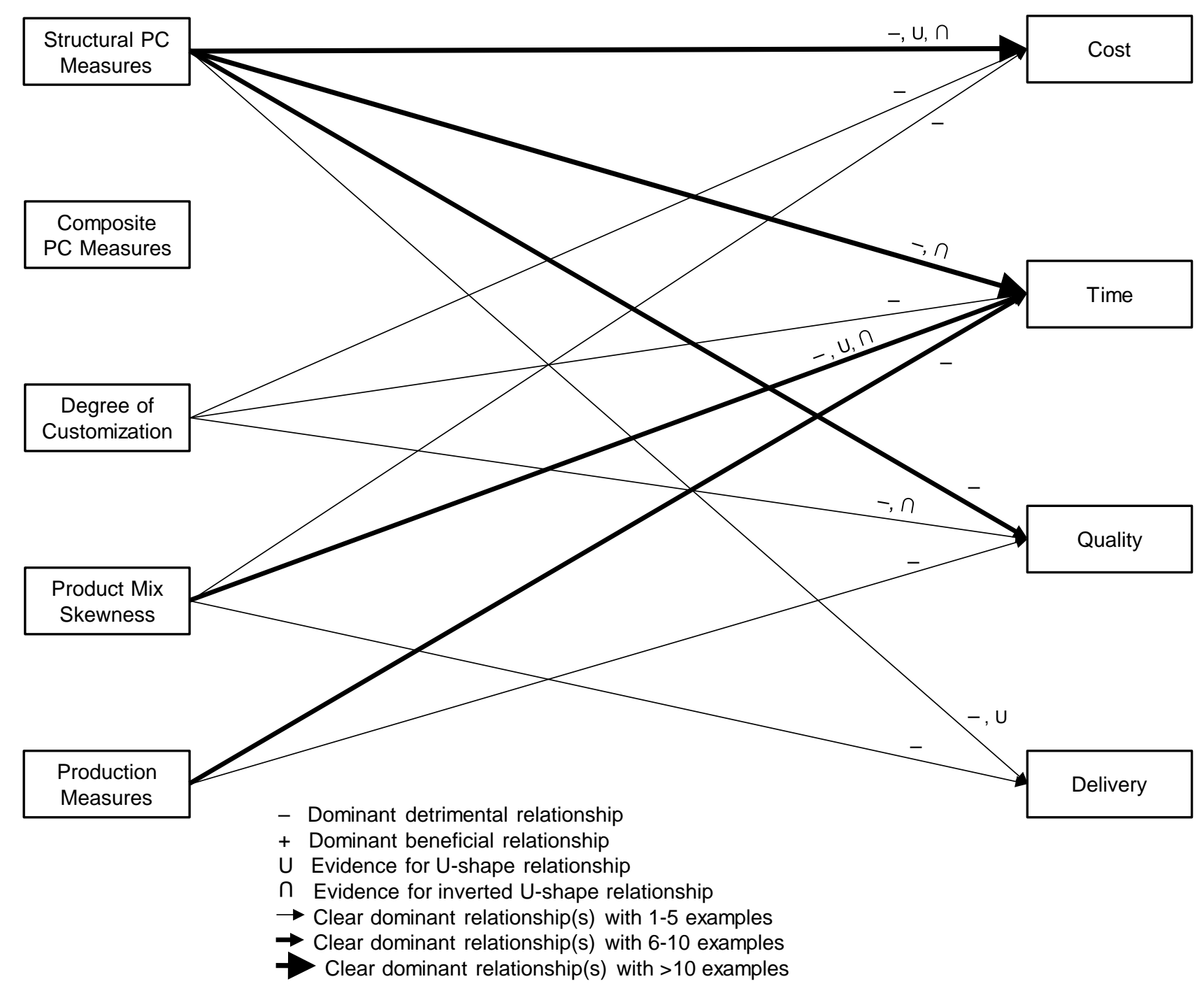

Figure 3. Summary of the relationships identified in the literature for various product complexity (PC) and operational performance measures

When reflecting on the total literature set, it is logical that similar results for time and cost performance were found as measures of time performance and cost performance are related. For example, a product requiring more processing time or lower productivity will also likely have higher manufacturing costs. This link between time and cost performance explains why some of the mediating and moderating factors appear in both sections: demand variability and forecast bias (Abernathy et al., 2000; Benjaafar et al., 2004; Koh et al., 2005), product and component similarity (Brahm et al., 2017; Busogi et al., 2017; Wan, 2016), use of lean manufacturing (MacDuffie et al., 1996; Squire et al., 2006), worker experience and skill level (Anderson, 1995; Brahm et al., 2017), machine flexibility (Nandkeolyar and Christy, 1992), and production sequencing (Berry and Cooper, 1999; MacDuffie et al., 1996). The discussion of increased supply chain coordination costs (or transaction costs) arising from high levels of PC was also discussed in multiple studies as one of the mechanisms underlying the PC $\rightarrow$ OP relationship (Ahmad and Shroeder, 2001; Ittner and MacDuffie, 1995; Jacobs and Swink, 2011). While quality and delivery performance measures are more distinct from time and cost measures, the underlying mechanisms of time and cost performance also apply to quality and delivery performance. 
The studies of PC's impact on operational costs and time performance in manufacturing and supply chain firms provide clear support for a unidirectional, negative, linear relationship, with some authors finding more nuanced relationships such as an inverted U-shape relationship (Wan, 2016; Wan and Dresner, 2015). The difference between a linear and an inverted U-shape PC $\rightarrow$ cost relationship is important to understand as it changes the method of management. A negative linear PC $\rightarrow$ cost relationship logically suggests that management should simply reduce PC and expect an equivalent reduction in costs. In contrast, an inverted U-shape curve suggests that adding variety beyond the vertex of the parabolic curve would be beneficial for the firm, generating economies of scope. This echoes the idea from marketing literature of greater unrelated variety causing worse performance and greater related variety improving performance (Palich et al., 2000; Wu et al., 2012). The exact shape of the relationship is likely to differ across firms based on the homogeneity or heterogeneity of their product assortments.

The few positive relationships that were identified were explained by the authors as either being anomalies (Eckstein et al., 2015; MacDuffie et al., 1996; Moreno and Terwiesch, 2017) or attributed to specific product variety management capabilities, such as machine flexibility (Gupta and Srinivasan, 1998; Ruiz-Torres and Mahmoodi, 2007). Given the weight of observations supporting a negative PC $\rightarrow$ OP relationship, it is unlikely that increasing performance with increasing product variety and complexity is the norm for most manufacturers.

Data for the cost analysis came primarily from case studies of production systems, such as the two study triads which investigated automotive manufacturers (Fisher and Ittner, 1999; Ittner and MacDuffie, 1995; MacDuffie et al., 1996) and beverage distribution firms (Wan, 2016; Wan and Dresner, 2015; Wan and Sanders, 2017). The studies which had access to production data from actual firms usually differentiated their PC measures to meet the needs of the specific production contexts. Though detailed product variety and complexity measures led to the inconclusive, ungeneralizable relationship between composite PC measures and costs in Figure 3, each case offered rich knowledge of very specific cost drivers related to PC, giving practical guidance to management on which types of variety which should be controlled.

The results of the industry analysis showed a dominance of the automotive and electronics manufacturers in the studies, two of the first industries to experience mass customization and the influx of product variants into assembly line manufacturing systems (Squire et al., 2006). This explains why the two industries are represented most in the literature sample. The underrepresentation of apparel, medical, and optical device manufacturers in the literature analyzed is surprising given the rise in customized footwear and medical devices (ElMaraghy et al., 2013; McIntosh et al., 2010; Squire et al., 2006). Further, the results revealed process industries operating with continuous production systems are underexplored in the product variety literature compared to manual batch assembly processes. While their level of PC at process industry firms is not comparable to that of the automotive industry, process industry firms are seeing rising levels of variety in customer demand (William L Berry and Cooper, 1999; Denton, Gupta and Jawahir, 2003; Tang and Huang, 2007; McIntosh et al., 2010) which warrants research into the PC and OP relationship in process industry firms. Anderson and Sedatole (2012) explore this in contextualizing the key variety factors in float glass production and show how only certain parameters had longer setup times (i.e. color and thickness). These insights illuminate the key features which impact performance and represent the contextual factors that Bausch and Pils (2009) call for in the diversity-performance literature. There is further opportunity for learning from the automotive sector to be applied to process industries in the field of product complexity and variety management.

Clustering studies in specific industries which use similar PC and OP measures makes it easier to compare, contrast, and generalize findings on $\mathrm{PC} \rightarrow \mathrm{OP}$ relationship. One industry-specific 
finding resulting from a clustered set of studies is that parts complexity in the automotive industry has a consistent, negative effect on productivity while model mix and options content have very little effect (Fisher and Ittner, 1999; Ittner and MacDuffie, 1995; MacDuffie et al., 1996). This information helps managers to be careful in adding new parts, such as new wire harnesses while being more open to additional car models or options.

The eighteen studies involving large production or survey datasets from many production firms employed quantitative techniques where PC as either an independent or control variable in the study and measures of OP as dependent variables. However, it was seen that where PC was used as a control variable rather than an independent variable, the article was less likely to find a statistically significant PC $\rightarrow$ OP relationship (Bortolotti et al., 2013; Christensen et al., 2007; Eckstein et al., 2015; Helkiö and Tenhiälä, 2013). The exact reason for this is unknown, but it could be due to issues in designing PC constructs or that PC becomes less significant in the presence of more dominant variables.

While authors argue that similarity in product and component variants may increase the efficiency of supply chain operations due to synergies in production and logistics (Brahm et al., 2017; Wan, 2016; Wan and Dresner, 2015; Zhang et al., 2007), others show that greater similarity between components in assembly operations leads to greater choice complexity and higher processing time (Busogi et al., 2017). Determining the right level of PC to offer which minimizes the choice complexity and maximizes synergies in the supply chain is a future area of research.

This study has its limitations. Comparing studies from different academic domains with differing methodologies, measurement methods, and industry cases should be done with caution since access to the raw data used in each article is limited (Tranfield et al., 2003). Further, a high frequency of occurrence for a given PC $\rightarrow$ OP relationship was interpreted as a trend, but the generalizability of the relationships might not extend beyond the cases from which is drawn. A further limitation of this study is the sample size of 43 articles. While the articles were thoroughly screened and coded, it could be that the criteria were too stringent or that the relevant contribution of the article was not reflected in its abstract. Finally, some papers contributing to this field were written before 1992 which may have added richness to the study, including Kekre and Srinivasan (1990) who found lower manufacturing costs linked to broader product lines in large US manufacturers.

\section{Conclusion}

This study presents a systematic literature review of the recent scholarly literature on product complexity and operational performance. Responding to manufacturers which must understand the impact of expanding product lines on their systems, researchers have birthed a growing body of insights regarding product variety and the mechanisms through product complexity affects operational performance. In the final literature sample of 93 articles from the past 25 years of research, product complexity showed a consistently negative relationship with manufacturing operational performance across cost, time, quality, and delivery performance measures. However, the evidence supporting the relationships with quality and delivery performance are not as strong as the relationships with cost and time performance measures. Literature coding revealed nearconsensus on the negative impact of product variety on general manufacturing costs, inventory costs, lead time, processing time, setup time, and process productivity. Delivery and quality appear the most under-researched performance measures and have the most inconclusive relationships with product complexity.

The negative impact of variety on most performance measures is a phenomenon experienced across industries and is a word of warning for manufacturers seeking to expand product lines. 
Before a firm invests in a variety-enabling strategy in operations, such as postponement, the firm could investigate the different levels of product complexity and how they affect their key performance indicators. Firms should also consider adding product variants similar to existing product variants, thus imposing a lower cost on the system. In the academia, researchers should include detailed variety measures specific to the industry-context when assessing the impact of variety on performance measures, as these revealed the most insightful findings in the literature review. Future research areas include investigating the relationship between product complexity and operational cost and time performance to understand when the relationship is linear and when it is logarithmic or quadratic.

\section{References}

Abbey, J.D., Guide, V.D.R. and Souza, G.C. (2013), "Delayed differentiation for multiple lifecycle products”, Production and Operations Management, Vol. 22 No. 3, pp. 588-602.

Abdulmalek, F.A., Rajgopal, J. and Needy, K.L. (2006), “A classification scheme for the process industry to guide the implementation of lean”, Engineering Management Journal, Vol. 18 No. 2, pp. 15-25.

Abernathy, F.H., Dunlop, J.T., Hammond, J.H. and Weil, D. (2000), "Control your inventory in a world of lean retailing.”, Harvard Business Review, Vol. 78 No. 6, pp. 169-172, 174, 176.

Ahmad, S. and Shroeder, R.G. (2001), "The impact of electronic data interchange on delivery performance”, Production and Operations Management, Vol. 10 No. 1, pp. 16-30.

Akinc, U. and Meredith, J.R. (2015), “Make-to-forecast: Customization with fast delivery”, International Journal of Operations and Production Management, Vol. 35 No. 5, pp. 728-750.

Akkerman, R. and van Donk, D.P. (2007), "Product prioritization in a two-stage food production system with intermediate storage”, International Journal of Production Economics, Vol. 108 No. 1-2, pp. 43-53.

Akkerman, R. and van Donk, D.P. (2009), "Product mix variability with correlated demand in two-stage food manufacturing with intermediate storage”, International Journal of Production Economics, Elsevier, Vol. 121 No. 2, pp. 313-322.

Alford, D., Sackett, P. and Nelder, G. (2000), “Mass customisation — an automotive perspective”, International Journal of Production Economics, Vol. 65 No. 1, pp. 99-110.

Alvarez, R., Bravo-Ortega, C. and Navarro, L. (2016), "Product Mix Changes and Performance in Chilean Plants", Industrial and Corporate Change, Vol. 25 No. 6, pp. 1-17.

Anderson, S. (1995), "Measuring the impact of produtc mix heterogeneity on manufacturing overhead cost”, The Accounting Review, Vol. 70 No. 3, pp. 363-387.

Anderson, S. and Sedatole, K.L. (2012), "Evidence on the Cost Hierarchy: The Association between Resource Consumption and Production Activities”, Journal of Management Accounting Research, Vol. 25, pp. 119-141.

Appelqvist, P., Chavez-Demoulin, V., Hameri, A.P., Heikkilä, J. and Wauters, V. (2013), "Turnaround across diverse global supply chains using shared metrics and change methodology: The case of Amer Sports Corporation”, International Journal of Operations and Production Management, Vol. 33 No. 5, pp. 622-647.

Aw, B.Y. and Lee, Y. (2009), "Product choice and market competition: The case of multiproduct electronic plants in Taiwan”, Scandinavian Journal of Economics, Vol. 111 No. 4, pp. 711-740.

Balakrishnan, A. and Geunes, J. (2003), "Production Planning with Flexible Product Specifications: An Application to Specialty Steel Manufacturing”, Operations Research, Vol. 51 No. 1, pp. 94-112.

Baldwin, J.R., Brown, W.M. and Gu, W. (2012), "Geographic market access and the effects of trade on length of production run, product diversity and plant scale of canadian manufacturing plants, 1974-1999”, Journal of Economic Geography, Vol. 12 No. 2, pp. 455-484.

Bausch, A. and Pils, F. (2009), "Product diversification strategy and financial performance: Meta-analytic evidence on causality and construct multidimensionality”, Review of Managerial Science, Vol. 3 No. 3, pp. 157-190.

Bayus, B.L. and Putsis, W.P. (1999), "Product Proliferation: An Empirical Analysis of Product Line Determinants and Market Outcomes”, Marketing Science, Vol. 18 No. 2, pp. 137-153.

Benjaafar, S., Kim, J.-S. and Vishwanadham, N. (2004), "On the Effect of Product Variety in Production-Inventory Systems”, Annals of Operations Research, Vol. 126 No. 1-4, pp. 71-101.

Berman, B. (2011), "Strategies to reduce product proliferation”, Business Horizons, "Kelley School of Business, Indiana University”, Vol. 54 No. 6, pp. 551-561.

Berry, W.L. and Cooper, M.C. (1999), "Manufacturing flexibility: methods for measuring the impact of product variety 
on performance in process industries”, Journal of Operations Management, Vol. 17, pp. 163-178.

Blome, C., Schoenherr, T. and Eckstein, D. (2014), "The impact of knowledge transfer and complexity on supply chain flexibility: A knowledge-based view”, International Journal of Production Economics, Elsevier, Vol. 147 No. PART B, pp. 307-316.

Boer, H., Holweg, M., Kilduff, M., Pagell, M., Schemenner, R. and Voss, C. (2015), “Making a meaningful contribution to theory”, International Journal of Operations \& Production Management, Vol. 35 No. 9, pp. $1231-1252$.

Bortolotti, T., Danese, P. and Romano, P. (2013), “Assessing the impact of just-in-time on operational performance at varying degrees of repetitiveness", International Journal of Production Research, Vol. 51 No. 4, pp. 1117-1130.

Bozarth, C.C., Warsing, D.P., Flynn, B.B. and Flynn, E.J. (2009), "The impact of supply chain complexity on manufacturing plant performance”, Journal of Operations Management, Vol. 27, pp. 78-93.

Brabazon, P.G., Maccarthy, B., Woodcock, A. and Hawkins, R.W. (2010), "Mass Customization in the Automotive Industry: Comparing Interdealer Trading and Reconfiguration Flexibilities in Order Fulfillment”, Production and Operations Management, Vol. 19 No. 5, pp. 489-502.

Brahm, F., Tarzijan, J. and Singer, M. (2017), "The impact of frictions in routine execution on economies of scope", Strategic Management Journal, Vol. 38 No. 10, pp. 2121-2142.

Van Den Broeke, M., Boute, R. and Samii, B. (2015), "Evaluation of product-platform decisions based on total supply chain costs", International Journal of Production Research, Taylor \& Francis, Vol. 53 No. 18, pp. 5545-5563.

Brun, A. and Pero, M. (2012), "Measuring variety reduction along the supply chain: The variety gap model", International Journal of Production Economics, Vol. 139, pp. 510-524.

Burgess, K., Singh, P.J. and Koroglu, R. (2006), "Supply chain management: a structured literature review and implications for future research”, International Journal of Operations \& Production Management, Vol. 26 No. 7, pp. 703-729.

Busogi, M., Ransikarbum, K., Oh, Y.G. and Kim, N. (2017), "Computational modelling of manufacturing choice complexity in a mixed-model assembly line”, International Journal of Production Research, Taylor \& Francis, Vol. 55 No. 20, pp. 5976-5990.

Caniato, F. and Größler, A. (2015), "The moderating effect of product complexity on new product development and supply chain management integration”, Production Planning \& Control, Taylor \& Francis, Vol. 7287 No. March, pp. 1-12.

Celano, G., Castagliola, P., Trovato, E. and Fichera, S. (2012), "The economic performance of the Shewhart t chart”, Quality and Reliability Engineering International, Vol. 28 No. 2, pp. 159-180.

Christensen, W.J., Germain, R.N. and Birou, L. (2007), "Variance vs average: Supply chain lead-time as a predictor of financial performance”, Supply Chain Management, Vol. 12 No. 5, pp. 349-357.

Christopher, M. (2000), “The agile supply chain: competing in volatile markets”, Industrial Marketing Management, Vol. 29, pp. 37-44.

Closs, D.J., Nyaga, G.N. and Voss, M.D. (2010), “The differential impact of product complexity, inventory level, and configuration capacity on unit and order fill rate performance”, Journal of Operations Management, Vol. 28, pp. $47-57$.

Cusumano, M.A. (1994), “The Limits of ‘Lean’”, Sloan Management Review, Vol. 35 No. 4, p. 27.

Deane, R.H. and Yang, J. (1992), "Product mix selection and closed manufacturing cell flow time performance", International Journal of Production Economics, Vol. 28 No. 2, pp. 157-169.

Denton, B., Gupta, D. and Jawahir, K. (2003), "Managing increasing product variety at integrated steel mills", Interfaces, Vol. 33 No. 2, pp. 41-53.

Ding, F.Y., Sun, H. and Kallaus, J. (2007), “Analysing product complexity related to product variety in a manufacturing firm with a case study at an automobile assembly plant”, International Journal of Logistics Systems and Management, Vol. 3 No. 3, p. 356.

Djassemi, M. (2005), “A simulation analysis of factors influencing the flexibility of cellular manufacturing”, International Journal of Production Research, Vol. 43 No. 10, pp. 2101-2111.

Eckstein, D., Goellner, M., Blome, C. and Henke, M. (2015), "The performance impact of supply chain agility and supply chain adaptability: The moderating effect of product complexity”, International Journal of Production Research, Taylor \& Francis, Vol. 53 No. 10, pp. 3028-3046.

ElMaraghy, H., Schuh, G., Elmaraghy, W., Piller, F., Schönsleben, P., Tseng, M. and Bernard, A. (2013), "Product variety management”, CIRP Annals - Manufacturing Technology, Vol. 62 No. 2, available at:https://doi.org/10.1016/j.cirp.2013.05.007.

Engström, T., Jonsson, D., Medbo, L. and Medbo, P. (1995), "Inter-relations between product variant codifications and assembly work for flexible manufacturing in autonomous groups”, Journal of Materials Processing Tech., Vol. 52 No. 1, pp. 133-140.

Er, M. and MacCarthy, B. (2006), "Managing product variety in multinational corporation supply chains”, Journal of 
Manufacturing Technology Management, Vol. 17 No. 8, pp. 1117-1138.

Erens, F.J. and Hegge, H.M.H. (1994), "Manufacturing and sales co-ordination for product variety”, International Journal of Production Economics, Vol. 37 No. 1, pp. 83-99.

Escobar-Saldívar, L.J., Smith, N.R. and González-Velarde, J.L. (2008), “An approach to product variety management in the painted sheet metal industry”, Computers and Industrial Engineering, available at:https://doi.org/10.1016/j.cie.2007.08.009.

Feng, P., Zhang, J., Wu, Z. and Yu, D. (2011), “An improved production planning method for process industries”, International Journal of Production Research, Vol. 49 No. 14, pp. 4223-4243.

Ferdows, K. and De Meyer, A. (1990), "Lasting improvements in manufacturing performance: in search of a new theory”, Journal of Operations Management, Vol. 9 No. 2, pp. 168-184.

Filippini, R., Forza, C. and Vinelli, A. (1998), "Trade-off and compatibility between performance: Definitions and empirical evidence”, International Journal of Production Research, Vol. 36 No. 12, pp. 3379-3406.

Fine, C.H. and Hax, A.C. (1985), "Manufacturing Strategy: A Methodology and an Illustration”, Interfaces, Vol. 15 No. 6, pp. 28-46.

Fisher, M., Ramdas, K. and Ulrich, K. (1999), “Component Sharing in the Management of Product Variety: A Study of Automotive Braking Systems”, Management Science, Vol. 45 No. 3, pp. 297-315.

Fisher, M.L. and Ittner, C.D. (1999), "The Impact of Product Variety on Automobile Assembly Operations: Empirical Evidence and Simulation Analysis”, Management Science, Vol. 45 No. 6, pp. 771-786.

Fixson, S.K. (2005), "Product architecture assessment: A tool to link product, process, and supply chain design decisions", Journal of Operations Management, Vol. 23 No. 3-4, pp. 345-369.

Forza, C., Salvador, F. and Trentin, A. (2008), "Form postponement effects on operational performance: a typological theory”, International Journal of Operations \& Production Management, Vol. 28 No. 11, pp. 1067-1094.

Fransoo, J.C. (1992), "Demand Management and Production Control in Process Industries”, International Journal of Operations \& Production Management, PT, Vol. 128 No. 2, pp. 187-196.

Gollop, F.M. (1997), “The pin factory revisited: Product diversification and productivity growth”, Review of Industrial Organization, Vol. 12 No. 3, pp. 317-334.

De Groote, X. and Yücesan, E. (2011), “THE IMPACT OF PRODUCT VARIETY ON LOGISTICS PERFORMANCE”, in White, P., Fu, M., Jain, S., Creasey, R. and Himmelspach, J. (Eds.), Proceedings of the 2011 Winter Simulation Conference, Phoenix, AZ, USA, pp. 2250-2259.

Gupta, D. and Srinivasan, M.M. (1998), “Note: How does product proliferation affect responsiveness?”, Management Science, Vol. 44 No. 7, pp. 1017-1020.

Gupta, Y.P. and Goyal, S. (1992), "Flexibility trade-offs in a random flexible manufacturing system: A simulation study”, International Journal of Production Research, Vol. 30 No. 3, pp. 527-557.

Handfield, R.B. and Pagell, M.D. (1995), “An analysis of the diffusion of flexible manufacturing systems”, Int. J. Production Economics, Vol. 39 No. 3, pp. 243-253.

Hayes, R.H. and Wheelwright, S.C. (1979), "Link manufacturing process and product life cycles”, Harvard Business Review, Vol. 57 No. 1, pp. 133-140.

Hegde, V.G., Kekre, S., Rajiv, S. and Tadikamalla, P.R. (2005), “Customization : Impact on Product and Process Performance”, Production and Operations Management, Vol. 14 No. 4, pp. 388-399.

Helkiö, P. and Tenhiälä, A. (2013), "A contingency theoretical perspective to the product-process matrix", International Journal of Operations \& Production Management, Vol. 33 No. 2, pp. 216-244.

Holweg, M. (2005), “The three dimensions of responsiveness”, International Journal of Operations and Production Management, Vol. 25 No. 7, pp. 603-622.

Holweg, M. and Pil, F.K. (2005), The Second Century: Reconnecting Customer and Value Chain through Build-toOrder, The MIT Press, Cambridge, MA.

Hsieh, K.L. and Tong, L.I. (2006), "Manufacturing performance evaluation for IC products”, International Journal of Advanced Manufacturing Technology, Vol. 28 No. 5-6, pp. 610-617.

Hu, S.J., Zhu, X., Wang, H. and Koren, Y. (2008), "Product variety and manufacturing complexity in assembly systems and supply chains”, CIRP Annals - Manufacturing Technology, Vol. 57 No. 1, pp. 45-58.

Huang, N. and Inman, R. (2010), "Product quality and plant build complexity", International Journal of Production Research, Vol. 48 No. 11, pp. 3105-3128.

Inman, R.R. and Blumenfeld, D.E. (2014), "Product complexity and supply chain design”, International Journal of Production Research, Vol. 52 No. 7, pp. 1956-1969.

Ittner, C.D. and MacDuffie, J.P. (1995), "Explaining Manufacturing Plant-Level Differences in Overhead: Structural and Cost Drivers in the World Auto Industry”, Production and Operations Management, Vol. 4 No. 4, pp. 312 334.

Jacobs, M.A. (2013), “Complexity: Toward an empirical measure”, Technovation, available at:https://doi.org/10.1016/j.technovation.2013.01.001. 
Jacobs, M.A. and Swink, M. (2011), "Product portfolio architectural complexity and operational performance: Incorporating the roles of learning and fixed assets”, Journal of Operations Management, Vol. 29, pp. 677-691.

Jensen, J.B., Malhotra, M.K. and Philipoom, P.R. (1996), "Machine dedication and process flexibility in a group technology environment”, Journal of Operations Management, Vol. 14 No. 1, pp. 19-39.

Kadakia, S.D., Donovan, T.E., Gupta, D., Beyene, W. and Bhatia, H. (1994), “Advanced Design and Modeling for Manufacturability of a Hybrid Package”, IEE Transactions on Components, Packaging, and Manufacturing Technology - Part B: Advanced Packaging, Vol. 17 No. 2, pp. 170-174.

Kampker, A., Schuh, G., Burggräf, P., Nowacki, C. and Swist, M. (2012), “Cost innovations by integrative product and production development”, CIRP Annals - Manufacturing Technology, Vol. 61 No. 1, pp. 431-434.

Keil, S., Eberts, D. and Lasch, R. (2014), "Redesigning product workflow for excellence”, IEEE Transactions on Semiconductor Manufacturing, Vol. 27 No. 4, pp. 539-550.

Kekre, S. and Srinivasan, K. (1990), “Broader Product Line: A Necessity to Achieve Success?”, Management Science, Vol. 36 No. 10, pp. 1216-1231.

Kim, K. and Chhajed, D. (2000), “Commonality in product design: cost saving, valuation change and cannibalization”, European Journal of Operational Research, Vol. 125 No. 3, pp. 602-621.

Koh, S.C.L., Gunasekaran, A. and Saad, S.M. (2005), “A business model for uncertainty management”, Benchmarking: An International Journal, Vol. 12 No. 4, pp. 383-400.

KPMG. (2011), Confronting Complexity: Research Findings and Insights, available at: http://www.kpmg.de/docs/20110126_Confronting-complexity_EN.pdf.

Lancaster, K. (1990), “The Economics of Product Variety: A Survey”, Marketing Science, Vol. 9 No. 3, pp. $189-206$.

Lanza, G., Peter, K., Rühl, J. and Peters, S. (2010), “Assessment of flexible quantities and product variants in production”, CIRP Journal of Manufacturing Science and Technology, Vol. 3 No. 4, pp. 279-284.

Lindemann, U., Maurer, M. and Braun, T. (2010), “Complexity in the context of product design”, Structural Complexity Management: An Approach for the Field of Product Design, Springer-Verlag, Berlin Heidelberg, pp. 21-42.

Loveland, J.L., Monkman, S.K. and Morrice, D.J. (2007), "Dell uses a new production-scheduling algorithm to accommodate increased product variety”, Interfaces, Vol. 37 No. 3, pp. 209-219.

MacDuffie, J.P., Sethuraman, K. and Fisher, M.L. (1996), "Product variety and manufacturing performance: evidence from the International Automotive Assembly Plant Study”, Management Science, Vol. 42 No. 3, pp. 350-369.

Mapes, J., New, C. and Szwejczewksi, M. (1997), "Performance trade-offs in manufacturing plants”, International Journal of Operations \& Production Management, Vol. 17 No. 10, pp. 1020-1033.

Marasco, A. (2008), “Third-party logistics: A literature review”, International Journal of Production Economics, Vol. 113 No. 1, pp. 127-147.

Maruthi, B.N. and Roshan Joseph, V. (1999), "Improving the Yield of Printed Circuit Boards Using Design of Experiments”, Quality Engineering, Vol. 12 No. 2, pp. 259-265.

McIntosh, R.I., Matthews, J., Mullineux, G. and Medland, A.J. (2010), "Late customisation: Issues of mass customisation in the food industry”, International Journal of Production Research, Vol. 48 No. 6, pp. 1557-1574.

Mocker, M. and Ross, J.W. (2017), “The problem with product proliferation”, Harvard Business Review, Vol. 2017 No. May-June, p. 8.

Moreno, A. and Terwiesch, C. (2017), "The Effects of Product Line Breadth : Evidence from the Automotive Industry The Effects of Product Line Breadth : Evidence from the Automotive Industry", Marketing Science, No. April.

Nagarur, N. and Azeem, A. (1999), "Impact of commonality and flexibility on manufacturing performance: A simulation study”, International Journal of Production Economics, Vol. 60-61, pp. 125-134.

Nandkeolyar, U. and Christy, D.P. (1992), "An investigation of the effect of machine flexibility and number of part families on system performance”, International Journal of Production Research, Vol. 30 No. 3, pp. 513-526.

Nazarian, E., Ko, J. and Wang, H. (2010), "Design of multi-product manufacturing lines with the consideration of product change dependent inter-task times , reduced changeover and machine flexibility”, Journal of Manufacturing Systems, Elsevier Ltd, Vol. 29 No. 1, pp. 35-46.

Novak, S. and Eppinger, S.D. (2001), “Sourcing By Design: Product Complexity and the Supply Chain”, Management Science, Vol. 47 No. 1, pp. 189-204.

O’Reilly, S., Kumar, A. and Adam, F. (2015), “The role of hierarchical production planning in food manufacturing SMEs”, International Journal of Operations \& Production Management, Vol. 35 No. 10, pp. 1362-1385.

OSHA. (2017), "SIC Division Structure”, OSHA Occupational Safety and Health Adminstration, available at: www.osha.gov (accessed 8 December 2017).

Palich, L.E., Cadrinal, L.B. and Miller, C.C. (2000), "Curvilinearity in the Diversification- Performance Linkage: an Examination of Over Three Decades of Research”, Strategic Management Journal, Vol. 21, pp. 155-174.

Pil, F.K. and Holweg, M. (2004), “Linking product variety to order-fulfillment strategies”, Interfaces, Vol. 34 No. 5, pp. 394-403.

Quelch, J.A. and Kenny, D. (1995), “Extend profits, not product lines”, Long Range Planning, Vol. 28 No. 1, p. 139. 
Rajagopalan, S. and Swaminathan, J.M. (2001), “A coordinated production planning model with capacity expansion and inventory management”, Management Science, Vol. 47 No. 11, pp. 1562-1580.

Ramdas, K. (2003), "Managing product variety: An integrative review and research directions”, PRODUCTION AND OPERATIONS MANAGEMENT, Vol. 12 No. 1, pp. 79-101.

Reis, A. da C., Scavarda, L.F. and Pancieri, B.M. (2013), "Product variety management: A synthesis of existing research”, African Journal of Business Management, Vol. 7 No. 1, pp. 39-55.

Rosenzweig, E.D. (2009), “A contingent view of e-collaboration and performance in manufacturing”, Journal of Operations Management, Vol. 27 No. 6, pp. 462-478.

Roy, R., Evans, R., Lowe, M.J. and Williams, D. (2011), “Addressing the impact of high levels of product variety on complexity in design and manufacture”, Vol. 000, pp. 1-12.

Ruiz-Torres, A.J. and Mahmoodi, F. (2007), “Impact of worker and shop flexibility on assembly cells”, International Journal of Production Research, Vol. 45 No. 6, pp. 1369-1388.

Ruiz-Torres, A.J. and Mahmoodi, F. (2008), “Analysis of multi-cell production systems considering cell size and worker flexibility”, International Journal of Industrial Engineering : Theory Applications and Practice, Vol. 15 No. 4, pp. 360-372.

Salvador, F., Forza, C. and Rungtusanatham, M. (2002), “Modularity, product variety, production volume, and component sourcing: Theorizing beyond generic prescriptions”, Journal of Operations Management, Vol. 20 No. 5, pp. 549-575.

Sardar, S. and Lee, Y.H. (2015), “Analysis of Product Complexity considering Disruption Cost in Fast Fashion Supply Chain”, Mathematical Problems in Engineering, Vol. 2015, available at:https://doi.org/10.1155/2015/670831.

Scavarda, L.F., Reichhart, A., Hamacher, S. and Holweg, M. (2010), "Managing product variety in emerging markets”, International Journal of Operations \& Production Management, Vol. 30 No. 2, pp. 205-224.

Schonberger, R.J. (1986), World Class Manufacturing, Free Press, New York, NY.

Scimago Lab. (2017), “Scimago Journal \& Country Rank”, Www.Scimagojr.Com, available at: www.scimagojr.com/journalrank.php (accessed 10 June 2017).

Seifoddini, H. and Djassemi, M. (1996), "Sensitivity analysis in cellular manufacturing system in the case of product mix variation”, Computers and Industrial Engineering, Vol. 31 No. 1/2, pp. 163-167.

Seifoddini, H. and Djassemi, M. (1997), "Determination of a flexibility range for cellular manufacturing systems under product mix variations”, International Journal of Production Research, Vol. 35 No. 12, pp. 3349-3366.

Seuring, S. and Müller, M. (2008), "From a literature review to a conceptual framework for sustainable supply chain management”, Journal of Cleaner Production, Vol. 16 No. 15, pp. 1699-1710.

Shah, R., Ball, G. and Netessine, S. (2017), "Plant Operations and Product Recalls in the Automotive Industry: An Empirical Investigation”, Management Science, Vol. 63 No. 8, pp. 2439-2459.

Silveira, G. Da. (1998), “A framework for the management of product variety”, International Journal of Operations \& Production Management, Vol. 18 No. 3, pp. 271-285.

Skinner, W. (1974), “The focused factory”, Harvard Business Review, Vol. 52 No. 3.

Squire, B., Brown, S., Readman, J. and Bessant, J. (2006), “The Impact of Mass Customisation on Manufacturing Trade-offs”, Production and Operations Management, Vol. 15 No. 1, pp. 10-21.

Stäblien, T., Holweg, M. and Miemczyk, J. (2011), “Theoretical versus actual product variety: how much customisation do customers really demand”, International Journal of Operations \& Production Management, Vol. 31 No. 3, p. 350.370 .

Storck, J. (2010), “Exploring improvement trajectories with dynamic process cost modelling: A case from the steel industry”, International Journal of Production Research, Vol. 48 No. 12, pp. 3493-3511.

Sun, H. and Ding, F.-Y. (2010), "Extended data envelopment models and a practical tool to analyse product complexity related to product variety for an automobile assembly plant”, International Journal of Logistics Systems and Management, Vol. 6 No. 1, pp. 99-112.

Swaminathan, J.M. and Nitsch, T.R. (2007), "Managing Product Variety in Automobile Assembly: The Importance of the Sequencing Point”, Interfaces, Vol. 37 No. 4, pp. 324-333.

Swaminathan, J.M. and Tayur, S.R. (1998), "Managing Broader Product Lines through Delayed Differentiation Using Vanilla Boxes”, Management Science, Vol. 44 No. 12-Part-2, pp. S161-S172.

Swink, M. and Hegarty, W.H. (1998), “Core manufacturing product differentiation”, International Journal of Operations \& Production Management, Vol. 18, pp. 374-396.

Tang, L. and Huang, L. (2007), “Optimal and near-optimal algorithms to rolling batch scheduling for seamless steel tube production”, International Journal of Production Economics, Vol. 105 No. 2, pp. 357-371.

Thirumalai, S. and Sinha, K.K. (2011), "Product Recalls in the Medical Device Industry: An Empirical Exploration of the Sources and Financial Consequences”, Management Science, Vol. 57 No. 2, pp. 376-392.

Thomé, A.M.T., Sousa, R.S. and Scavarda do Carmo, L.F.R. (2014), “Complexity as contingency in sales and operations planning”, Industrial Management \& Data Systems, Vol. 114 No. 5, pp. 678-695. 
Thomé, M.T.A., Sousa, R.S. and do Carmo, L.F.R.R.S. (2014), “The impact of sales and operations planning practices on manufacturing operational performance”, International Journal of Production Research, Vol. 52 No. 7, pp. 2108-2121.

Thonemann, U.W. and Bradley, J.R. (2002), “The effect of product variety on supply-chain performance”, European Journal of Operational Research, Vol. 143 No. 3, pp. 548-569.

Tracey, M. (2004), “Transportation Effectiveness and Manufacturing Firm Performance”, International Journal of Logistics Management, Vol. 15 No. 2, pp. 31-50.

Tranfield, D., Denyer, D. and Smart, P. (2003), “Towards a Methodology for Developing Evidence-Informed Management Knowledge by Means of Systematic Review”, British Journal of Management, Vol. 14, pp. 207222.

Trattner, A.L., Hvam, L., Herbert-Hansen Lee, Z.N. and Raben, C. (2017), "Product variety, product complexity and manufacturing operational performance: A systematic literature review”, EurOMA Conference, Edingburgh, United Kingdom, available at: http://orbit.dtu.dk/en/publications/product-variety-product-complexity-andmanufacturing-operational-performance-a-systematic-literature-review(2ee0c783-09bf-4f32-9785870adfa30055).html.

Trentin, A., Perin, E. and Forza, C. (2012), “Product configurator impact on product quality”, International Journal of Production Economics, Elsevier, Vol. 135 No. 2, pp. 850-859.

Um, J. (2017), “Improving supply chain flexibility and agility through variety management”, The International Journal of Logistics Management, Vol. 28 No. 2, pp. 464-487.

Vachon, S. and Klassen, R.D. (2002), “An exploratory investigation of the effects of supply chain complexity on delivery performance”, IEEE Transactions on Engineering Management, Vol. 49 No. 3, pp. 218-230.

Vilas, C.O. y and Vandaele, N. (2002), “A cost and operations based product heterogeneity index”, International Journal of Production Economics, Vol. 79 No. 1, pp. 45-55.

Wan, X. (2016), “Timing of the Effects: A Dynamic Analysis of Pack-Size Variety, Demand, and Cost”, Journal of Business Logistics, Vol. 37 No. 3, pp. 271-283.

Wan, X. and Dresner, M.E. (2015), “Closing the Loop: An Empirical Analysis of the Dynamic Decisions Affecting Product Variety”, Decision Sciences, Vol. 46 No. 6, pp. 1141-1164.

Wan, X., Dresner, M.E. and Evers, P.T. (2014), “Assessing the dimensions of product variety on performance: The value of product line and pack size”, Journal of Business Logistics, Vol. 35 No. 3, pp. 213-224.

Wan, X., Evers, P.T. and Dresner, M.E. (2012), "Too much of a good thing: The impact of product variety on operations and sales performance”, Journal of Operations Management, Vol. 30, pp. 316-324.

Wan, X. and Sanders, N.R. (2017), “The negative impact of product variety: Forecast bias, inventory levels, and the role of vertical integration”, International Journal of Production Economics, Elsevier B.V., Vol. 186 No. July 2016, pp. 123-131.

Ward, J., Zhang, B., Jain, S., Fry, C., Olavson, T., Mishal, H., Amaral, J., et al. (2010), "HP transforms product portfolio management with operations research”, Interfaces, Vol. 40 No. 1, pp. 17-32.

Wilson, S.A. and Perumal, A. (2009), Waging War on Complexity Costs, McGraw-Hill Education, New York, NY.

Wong, H. and Eyers, D. (2011), “An analytical framework for evaluating the value of enhanced customisation: An integrated operations-marketing perspective”, International Journal of Production Research, Vol. 49 No. 19, pp. 5779-5800.

Wong, H. and Lesmono, D. (2013), “On the evaluation of product customization strategies in a vertically differentiated market”, International Journal of Production Economics, Elsevier, Vol. 144 No. 1, pp. 105-117.

Wu, D., Wu, X. and Zhou, H. (2012), "International expansion and firm performance in emerging market: evidence from China”, Chinese Management Studies, Vol. 6 No. 3, pp. 509-528.

Xia, N. and Rajagopalan, S. (2009), “Standard vs. Custom Products: Variety, Lead Time, and Price Competition”, Marketing Science, Vol. 28 No. 5, pp. 887-900.

Yang, J. and Deane, R.H. (1993), "Setup time reduction and competitive advantage in a closed manufacturing cell”, European Journal of Operational Research, Vol. 69 No. 3, pp. 413-423.

Yeh, K. and Chu, C. (1991), “Adaptive strategies for coping with product variety decisions”, International Journal of Operations and Production Management, Vol. 11 No. 8, pp. 35-47.

Zeltzer, L., Limère, V., Van Landeghem, H., Aghezzaf, E.H. and Stahre, J. (2013), "Measuring complexity in mixedmodel assembly workstations”, International Journal of Production Research, Vol. 51 No. 15, pp. 4630-4643.

Zhang, M. and Tseng, M.M. (2007), “A Product and Process Modeling Based Approach to Study Cost Implications of Product Variety in Mass Customization”, IEEE Transactions on Engineering Management, Vol. 54 No. 1, pp. 130-144.

Zhang, X., Chen, R. and Ma, Y. (2007), “An empirical examination of response time, product variety and firm performance”, International Journal of Production Research, Vol. 45 No. 14, pp. 3135-3150.

Zipkin, P. (2001), “The Limits of Mass Customization”, MIT Sloan Management Review, Vol. 42 No. 3, pp. 81-87. 


\section{Appendix A: Manufacturing Operational Performance Measures Identified in Literature}

\section{Table 5. Manufacturing Operational Performance Measures Identified in the Literature Sample}

\begin{tabular}{|c|c|c|}
\hline $\begin{array}{l}\text { Manufacturing Operational } \\
\text { Performance Measure }\end{array}$ & Definition & Publication \\
\hline \multicolumn{3}{|l|}{ Costs } \\
\hline \multicolumn{3}{|l|}{ Manufacturing costs (general) } \\
\hline Manufacturing Costs (general) & $\begin{array}{l}\text { Cost of production for one product (e.g. costs of material, } \\
\text { labour and machine processing, and tooling) }\end{array}$ & $\begin{array}{l}\text { (Alford et al., 2000; Berman, 2011; Lanza et } \\
\text { al., 2010; Moreno and Terwiesch, 2017; } \\
\text { Silveira, 1998; Sun and Ding, 2010; Wong and } \\
\text { Eyers, 2011; Zhang and Tseng, 2007) }\end{array}$ \\
\hline $\begin{array}{l}\text { Manufacturing and logistics } \\
\text { costs }\end{array}$ & $\begin{array}{l}\text { Manufacturing and logistics costs (e.g. packaging, } \\
\text { inventory holding, distribution. logistics) }\end{array}$ & $\begin{array}{l}\text { (Ding et al., 2007; Roy et al., 2011; Wan, } \\
\text { 2016; Wan and Dresner, 2015) }\end{array}$ \\
\hline $\begin{array}{l}\text { Direct manufacturing costs } \\
\text { (survey) }\end{array}$ & $\begin{array}{l}\text { Manufacturing costs relative to competitors, normalized } \\
5 \text { or } 7 \text { pt. Likert scale }\end{array}$ & $\begin{array}{l}\text { (Bozarth et al., 2009; Helkiö and Tenhiälä, } \\
\text { 2013) }\end{array}$ \\
\hline $\begin{array}{l}\text { Manufacturing and other costs } \\
\text { (survey) }\end{array}$ & $\begin{array}{l}\text { Costs relative to competitors, including design, } \\
\text { manufacturing, component, delivery, and servicing costs, } \\
5 \text { pt. Likert scale }\end{array}$ & $\begin{array}{l}\text { (Van Den Broeke et al., 2015; Caniato and } \\
\text { Größler, 2015; Eckstein et al., 2015; Squire et } \\
\text { al., 2006) }\end{array}$ \\
\hline Added value (ranked) & $\begin{array}{l}\text { Manufacturing cost - added value per GBP of employee } \\
\text { cost, ranked within sample }\end{array}$ & (Mapes et al., 1997) \\
\hline Unit and inventory cost & $\begin{array}{l}\text { Unit costs at retailer, inventory holding costs, and } \\
\text { backorder costs }\end{array}$ & (Thonemann and Bradley, 2002) \\
\hline Efficiency & $\begin{array}{l}\text { Survey measure of unit manufacturing cost, inventory } \\
\text { turns, and cycle time }\end{array}$ & (Bortolotti et al., 2013) \\
\hline \multicolumn{3}{|l|}{ Direct labour costs } \\
\hline Direct labour costs & $\begin{array}{l}\text { Direct labour hours per unit produced, measure of the } \\
\text { value adding activities }\end{array}$ & $\begin{array}{l}\text { (Fisher and Ittner, 1999; Ittner and MacDuffie, } \\
\text { 1995) }\end{array}$ \\
\hline Labour productivity & Hours of working effort per part & (MacDuffie et al., 1996) \\
\hline Manufacturing Overhead & Cost of indirect factory personnel & $\begin{array}{l}\text { (Anderson, 1995; Anderson and Sedatole, } \\
\text { 2012; Brun and Pero, 2012; Fisher and Ittner, } \\
\text { 1999; Ittner and MacDuffie, 1995; Scavarda et } \\
\text { al., 2010) }\end{array}$ \\
\hline \multicolumn{3}{|l|}{ Inventory costs } \\
\hline Inventory cost & Sum of holding costs (some include backorder costs) & $\begin{array}{l}\text { (Abbey et al., 2013; Abernathy et al., 2000; } \\
\text { Appelqvist et al., 2013; Benjaafar et al., 2004; } \\
\text { Brabazon et al., 2010; Escobar-Saldívar et al., } \\
\text { 2008; Fisher and Ittner, 1999; Moreno and } \\
\text { Terwiesch, 2017; O’Reilly et al., 2015; Pil and } \\
\text { Holweg, 2004; Seifoddini and Djassemi, 1996; } \\
\text { Wan and Sanders, 2017; Ward et al., 2010) }\end{array}$ \\
\hline $\begin{array}{l}\text { Supply-Demand Mismatch } \\
\text { costs }\end{array}$ & $\begin{array}{l}\text { Cost of discounting inventory due to oversupply, } \\
\text { calculated as manufacturing spend on incentives }\end{array}$ & (Moreno and Terwiesch, 2017) \\
\hline Inventory and capacity costs & $\begin{array}{l}\text { Costs of inventory, cycle stock, and capacity purchase } \\
\text { costs from external suppliers }\end{array}$ & (Rajagopalan and Swaminathan, 2001) \\
\hline \multicolumn{3}{|c|}{ (2: } \\
\hline \multicolumn{3}{|l|}{ Lead Time } \\
\hline Lead time (general) & $\begin{array}{l}\text { Time from order to delivery, includes design time if a } \\
\text { custom product }\end{array}$ & $\begin{array}{l}\text { (Akinc and Meredith, 2015; Akkerman and } \\
\text { van Donk, 2007, 2009; Berman, 2011; } \\
\text { Brabazon et al., 2010; Christensen et al., 2007; } \\
\text { Holweg, 2005; Inman and Blumenfeld, 2014; } \\
\text { Vilas and Vandaele, 2002; Ward et al., 2010; } \\
\text { Wong and Lesmono, 2013; Xia and } \\
\text { Rajagopalan, 2009; Zhang et al., 2007) }\end{array}$ \\
\hline Lead time (quoted, ranked) & Avg. lead time quoted to customer, ranked within sample & (Mapes et al., 1997) \\
\hline Lead time (expected) & Expected lead time for order fulfilment & (Thonemann and Bradley, 2002) \\
\hline Lead time (survey) & $\begin{array}{l}\text { Average lead time relative to competitors, questions } \\
\text { measured on Likert scale }\end{array}$ & $\begin{array}{l}\text { (Caniato and Größler, 2015; Squire et al., } \\
\text { 2006; Vachon and Klassen, 2002) }\end{array}$ \\
\hline
\end{tabular}




\begin{tabular}{|c|c|}
\hline Responsiveness (backlog) & $\begin{array}{l}\text { Number of items currently being worked on by the } \\
\text { facility, used to indicate lead time }\end{array}$ \\
\hline Flexibility & $\begin{array}{l}\text { Survey measure including sub measures of ability to } \\
\text { adjust orders last minute and reduce lead time }\end{array}$ \\
\hline \multicolumn{2}{|l|}{ Process Time } \\
\hline Order and process time & Time from order to finish of manufacturing \\
\hline Process time & Time to assemble or process a product in manufacturing \\
\hline Processing time (survey) & Processing time based on survey responses \\
\hline \multicolumn{2}{|l|}{ Setup Time } \\
\hline Setup Time & Time used to set up machinery for product change \\
\hline Run length / lot size & $\begin{array}{l}\text { Production run length (e.g. total sales divided by number } \\
\text { products, or batch size) }\end{array}$ \\
\hline Batch size & The volume of product produced per batch \\
\hline \multicolumn{2}{|l|}{ Productivity } \\
\hline Process productivity & $\begin{array}{l}\text { Throughput, saleable product produced per hour } \\
\text { production }\end{array}$ \\
\hline Downtime & Minutes producing non-saleable product per day \\
\hline Total factor productivity & $\begin{array}{l}\text { Reduction in average costs not accounted for by change } \\
\text { in input prices (i.e. labour and efficiency related) }\end{array}$ \\
\hline Log of volume & Natural logarithm of production volume \\
\hline Speed & Production speed \\
\hline \multicolumn{2}{|l|}{ Quality } \\
\hline Quality (general) & Product quality \\
\hline Product recalls & Number of product recalls \\
\hline Product performance (survey) & $\begin{array}{l}\text { Product performance relative to competitors, } 3 \text { questions } \\
\text { with } 7 \text { pt. Likert scale, normalized }\end{array}$ \\
\hline Quality (survey) & $\begin{array}{l}\text { Quality durability, reliability, and others such as } \\
\text { conformance, \% returns, and \% final pass inspection, } \\
\text { relative to competitors, questions measured on } 5 \text { pt. } \\
\text { Likert scale }\end{array}$ \\
\hline Customer returns (ranked) & customer returns \% of output, ranked within sample \\
\hline Product reliability & Customer rank from consumer reports \\
\hline Human errors & Number of human errors in production \\
\hline Rework & $\%$ or parts requiring rework \\
\hline Defects & Number of defects per 100 vehicles due to assembly \\
\hline Mismatch errors & $\begin{array}{l}\text { Errors seen in the field by customers where } \\
\text { customization did not meet the performance desired by } \\
\text { the customer (design errors) }\end{array}$ \\
\hline Manufacturing errors & $\begin{array}{l}\text { Errors where manufacturing process is not capable of } \\
\text { achieving the constraints set by the customer }\end{array}$ \\
\hline Repair costs & Function of repair costs of products built \\
\hline Inspection costs & Costs of inspection \\
\hline Yield & Percentage of good products coming from a process \\
\hline
\end{tabular}

\author{
(Gupta and Srinivasan, 1998) \\ (Blome et al., 2014; Caniato and Größler, \\ 2015)
}

(Er and MacCarthy, 2006)

(Busogi et al., 2017; Deane and Yang, 1992; Djassemi, 2005; Engström et al., 1995; Gupta and Goyal, 1992; Huang and Inman, 2010; Jensen et al., 1996; Keil et al., 2014; Nagarur and Azeem, 1999; Nazarian et al., 2010; RuizTorres and Mahmoodi, 2007, 2008, Seifoddini and Djassemi, 1996, 1997; Yang and Deane, 1993; Zhang et al., 2007)

(Vachon and Klassen, 2002)

(Anderson, 1995; Brun and Pero, 2012; Cusumano, 1994; Escobar-Saldívar et al., 2008; Kampker et al., 2012; Sardar and Lee, 2015)

(Baldwin et al., 2012; Celano et al., 2012)

(Berry and Cooper, 1999)

(Aw and Lee, 2009; Berry and Cooper, 1999; Nagarur and Azeem, 1999; Nandkeolyar and Christy, 1992)

(Anderson and Sedatole, 2012)

(Alvarez et al., 2016; Gollop, 1997)

(Brahm et al., 2017)

(Silveira, 1998)
(Berman, 2011; Silveira, 1998)

(Shah et al., 2017; Thirumalai and Sinha, 2011)

(Helkiö and Tenhiälä, 2013)

(Caniato and Größler, 2015; Squire et al., 2006; Thomé, Sousa and Scavarda do Carmo, 2014)

(Mapes et al., 1997)

(Novak and Eppinger, 2001)

(Brun and Pero, 2012)

(Fisher and Ittner, 1999)

(MacDuffie et al., 1996)

(Hegde et al., 2005)

(Hegde et al., 2005)

(Huang and Inman, 2010)

(Celano et al., 2012; Huang and Inman, 2010)

(Hsieh and Tong, 2006; Kadakia et al., 1994; Maruthi and Roshan Joseph, 1999)

\section{Delivery}

Delivery Performance (survey)

On-time delivery
Delivery performance relative to competitors, 3-7 questions with . Likert scale, normalized $\%$ orders delivered on time
(Bortolotti et al., 2013; Helkiö and Tenhiälä, 2013; Rosenzweig, 2009; Tracey, 2004) (Ahmad and Shroeder, 2001; Appelqvist et al., 2013) 


\begin{tabular}{lll}
\hline On-time delivery (rank) & \% items delivered on time, ranked within sample & (Koh et al., 2005; Mapes et al., 1997) \\
Delivery reliability (survey) & $\begin{array}{l}\text { Delivery reliability, speed, lead time, and \% on time } \\
\text { relative to competitors, survey questions, Likert scale }\end{array}$ & $\begin{array}{l}\text { (Caniato and Größler, 2015; Squire et al., } \\
\text { 2006; Thomé, Sousa and Scavarda do Carmo, } \\
\text { 2014; Vachon and Klassen, 2002) }\end{array}$ \\
$\begin{array}{ll}\text { (Christensen et al., 2007) } \\
\text { Vead time variability }\end{array}$ & $\begin{array}{l}\text { Variance in lead time, survey } \\
\text { Order fulfilment rate }\end{array}$ & $\begin{array}{l}\text { \% of orders fulfilled completely 2010; Wan et al., 2012, 2014) } \\
\text { Unit fill rate }\end{array}$ \\
$\begin{array}{l}\text { \%uality and delivery } \\
\text { performance }\end{array}$ & $\begin{array}{l}\text { Performance on product quality, service level, and on- } \\
\text { time delivery compliance, 5 pt. Likert scale }\end{array}$ & (Eckstein et al., 2015) \\
\hline
\end{tabular}

